\title{
Seepage Study of McLeod Creek and East Canyon Creek near Park City, Summit County, Utah, 2004
}



Scientific Investigations Report 2005-5164

Prepared in Cooperation with the Snyderville Basin Water Reclamation District

U.S. Department of the Interior

U.S. Geological Survey 
Cover: East Canyon Creek near Kimball Junction, Utah.

Photo by C.D. Wilkowske, June 24, 2004. 


\section{Seepage Study of McLeod Creek and East Canyon Creek near Park City, Summit County, Utah, 2004}

By C.D. Wilkowske

Prepared in Cooperation with the Snyderville Basin Water Reclamation District

Scientific Investigations Report 2005-5164 


\section{U.S. Department of the Interior \\ Gale A. Norton, Secretary}

\section{U.S. Geological Survey \\ P. Patrick Leahy, Acting Director}

U.S. Geological Survey, Reston, Virginia: 2005

Revised and reprinted: 20xx

For sale by U.S. Geological Survey, Information Services

Box 25286, Denver Federal Center

Denver, CO 80225

For more information about the USGS and its products:

Telephone: 1-888-ASK-USGS

World Wide Web: http://www.usgs.gov/ 


\section{Contents}

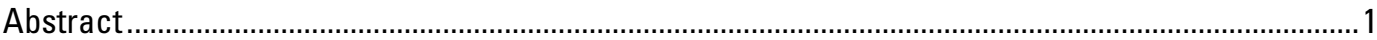

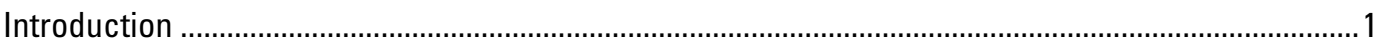

Purpose and Scope .................................................................................................................

Methods used to determine seepage along McLeod Creek and East Canyon Creek..................... 5

Streamflow Measurements ……………………………...........................................

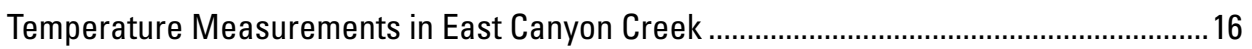

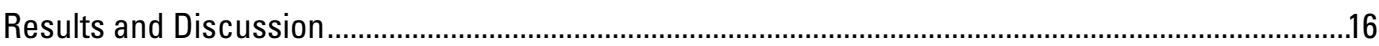

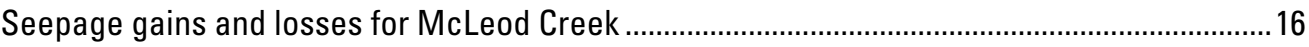

Seepage gains and losses for East Canyon Creek ................................................................. 19

Heat Tracing in East Canyon Creek ..................................................................................... 20

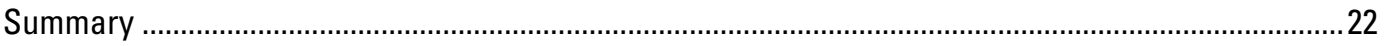

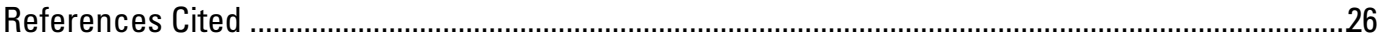

\section{Figures}

Figure 1. Location of the study area, Park City, Snyderville Basin, and adjacent areas, Summit County, Utah

Figure 2. Location of the measurement sites along McLeod Creek near Park City, Utah ..................... 3

Figure 3. Location of the measurement sites along East Canyon Creek near Park City, Utah............. 4

Figure 4. Discharge at U.S. Geological Survey streamflow-gaging station McLeod Creek near Park City, Utah

Figure 5. Discharge at U.S. Geological Survey streamflow-gaging station East Canyon Creek below I-80 Rest Stop near Park City, Utah

Figure 6. Discharge at U.S. Geological Survey streamflow-gaging station East Canyon Creek near Jeremy Ranch, Utah. 13

Figure 7. Discharge along East Canyon Creek near Park City, Utah ................................................... 14

Figure 8. Streambed piezometer installed at site ECC-7, near Park City, Utah...................................17

Figure 9. Measured and apparent average seepage gain for reaches of McLeod Creek

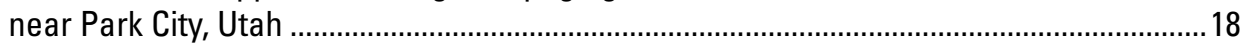

Figure 10. Discharge along McLeod Creek near Park City, Utah..........................................................19

Figure 11. Measured and apparent average seepage gain or loss for reaches of East Canyon Creek near Park City, Utah

Figure 12. Water temperature and streambed piezometer temperature in East Canyon Creek at site ECC-2, near Park City, Utah

Figure 13. Water temperature and streambed piezometer temperature in East Canyon Creek at site ECC-4, near Park City, Utah 24

Figure 14. Water temperature and streambed piezometer temperature in East Canyon Creek at site ECC-7, near Park City, Utah 


\section{Tables}

Table 1. Discharge measurements made on June 24, 2004, at selected East Canyon Creek sites near Park City, Utah.

Table 2. Latitude, longitude, and site description of seepage measurement sites on McLeod Creek and East Canyon Creek near Park City, Utah

Table 3. Measurements of discharge, specific conductance, water temperature, $\mathrm{pH}$, and and concentration of dissolved oxygen in water from McLeod Creek near Park City, Utah.

Table 4. Measurements of discharge, specific conductance, water temperature, $\mathrm{pH}$, and concentration of dissolved oxygen in water from East Canyon Creek near Park City, Utah.

Table 5. Difference in recorded discharge at streamflow-gaging stations on McLeod and East Canyon Creeks near Park City, Utah.

Table 6. Estimated discharge fluctuation during seepage measurements on McLeod Creek near Park City, Utah.....

Table 7. Estimated discharge fluctuation during seepage measurements on East Canyon Creek near Park City, Utah.

Table 8. Calculated seepage gains and losses for McLeod Creek near Park City, Utah ................... 17

Table 9. Calculated seepage gains and losses for East Canyon Creek near Park City, Utah...........20

\section{Conversion Factors}

\begin{tabular}{lcl}
\hline & Multiply & \multicolumn{1}{c}{ By } \\
\hline & Length & \\
\hline inch (in.) & 2.54 & centimeter $(\mathrm{cm})$ \\
foot $(\mathrm{ft})$ & 0.3048 & meter $(\mathrm{m})$ \\
mile (mi) & 1.609 & kilometer $(\mathrm{km})$ \\
\hline & Area & \\
\hline square mile $\left(\mathrm{mi}^{2}\right)$ & 2.590 & square kilometer $\left(\mathrm{km}^{2}\right)$ \\
\hline & Flow rate & \\
\hline cubic foot per second $\left(\mathrm{ft}^{3} / \mathrm{s}\right)$ & 0.02832 & cubic meter per second $\left(\mathrm{m}^{3} / \mathrm{s}\right)$ \\
cubic foot per second per mile $\left(\mathrm{ft}^{3} / \mathrm{s} / \mathrm{mi}\right)$ & 0.0176 & cubic meter per kilometer $\left(\mathrm{m}^{3} / \mathrm{km}\right)$ \\
\hline
\end{tabular}

Temperature in degrees Celsius $\left({ }^{\circ} \mathrm{C}\right)$ may be converted to degrees Fahrenheit $\left({ }^{\circ} \mathrm{F}\right)$ as follows:

${ }^{\circ} \mathrm{F}=\left(1.8 x^{\circ} \mathrm{C}\right)+32$

Horizontal coordinate information is referenced to the North American Datum of 1983 (NAD 83).

Specific conductance is given in microsiemens per centimeter at 25 degrees Celsius $\left(\mu \mathrm{S} / \mathrm{cm}\right.$ at $\left.25^{\circ} \mathrm{C}\right)$. Concentrations of chemical constituents in water are given either in milligrams per liter (mg/L) or micrograms per liter ( $\mu \mathrm{g} / \mathrm{L})$. 


\title{
Seepage Study of McLeod Creek and East Canyon Creek near Park City, Summit County, Utah, 2004
}

\author{
By C.D. Wilkowske
}

\section{Abstract}

Seepage investigations on McLeod Creek downstream of U.S. Geological Survey streamflow-gaging station McLeod Creek near Park City, Utah, and its confluence with Kimball Creek during the summer of 2004 indicate that this section of the creek is a gaining reach. The total seepage gains ranged from 1.8 to 2.7 cubic feet per second, or a 32 to 55 percent gain. The apparent average total seepage gain was 2.2 cubic feet per second, or an average 42 percent gain. Seepage investigations from the U.S. Geological Survey streamflow-gaging station at East Canyon Creek below I-80 Rest Stop near Park City, Utah, to the station at East Canyon Creek near Jeremy Ranch, Utah, indicate that this section of East Canyon Creek is a slightly losing reach. The total seepage losses ranged from -1.2 to -2.0 cubic feet per second. This is a loss of between -18 and -27 percent from discharge measured at the upstream gaging station. The apparent average total seepage loss for the reach was -1.0 cubic feet per second, or -18 percent. Seepage information also was obtained along East Canyon Creek by using water-temperature data recorded in three shallow streambed piezometers. Surface-water temperature also was recorded at these locations. These water-temperature profiles indicate a seepage loss at all three locations along East Canyon Creek. This seepage loss appears to decrease in September and October.

\section{Introduction}

The study area lies in the Snyderville Basin north of Park City, in Summit County, Utah (fig. 1). Surface water in the basin originates in the Wasatch Mountains to the south and west of the study area. East Canyon Creek begins as McLeod Creek, which receives water from snowmelt and from the Spiro Tunnel near Park City, Utah (Brooks and others, 1998). McLeod Creek generally gains surface water from small streams and springs as it flows through the eastern side of Snyderville Basin. This report considers East Canyon Creek to start where Kimball Creek joins McLeod Creek just above U.S. Geological Survey (USGS) streamflow-gaging station 10133650, East Canyon Creek below I-80 Rest Stop near Park City, Utah. East Canyon Creek gains surface water from a number of small perennial streams and a waste-water treatment plant as it flows north and west to East Canyon Reservoir. The perennial streams to the east of Kimball Junction are fed by springs south of Interstate 80 . Streams to the west of Kimball Junction drain from small canyons in the Wasatch Mountains. The area of the drainage basin considered in this study is $57.2 \mathrm{mi}^{2}$.

The streambed for both streams in the vicinity of the study area is composed of mud, sand, gravel, and cobbles along most of its reach. The stream banks are vegetated mainly with grasses and willows. The upper reach of McLeod Creek in the study area is heavily diverted for irrigation (fig. 2). Numerous small pumps also are installed in the creek for small-scale lawn irrigation. The creek is diverted into a number of small artificial ponds that were built for housing developments along the upper end of the study area. There are no irrigation diversions in the lower reach of McLeod Creek, however, there are irrigation returns and inflows from springs that add water. East Canyon Creek has relatively few diversions along the reach in the study area (fig. 3). There is one pumped diversion for the Glenwild Golf Club, which is shown as OUT-2 in figure 3, and one surface-water diversion used by Summit Water Distribution Company (shown as OUT-4 on figure 3). The Snyderville Basin Water Reclamation District operates the East Canyon Water Reclamation Facility at the lower end of the reach (fig. 3). Effluent from the treatment plant enters the stream just above USGS streamflow-gaging station 10133800, East Canyon Creek near Jeremy Ranch, Utah (IN-20 on fig. 3).

Holmes and others (1986) conducted a seepage study on East Canyon Creek on October 27, 1983. A $0.6 \mathrm{ft}^{3} / \mathrm{s}$ gain was measured from the beginning of East Canyon Creek to just above the inflow from Threemile Canyon. From Threemile Canyon to Toll Canyon, a $1.45 \mathrm{ft}^{3} / \mathrm{s}$ gain was measured. From Toll Canyon to near the present location of the gage at East Canyon Creek near Jeremy Ranch, Utah, a $0.7 \mathrm{ft}^{3} / \mathrm{s}$ gain was measured. The total seepage gain measured along this reach from the start of the creek to near streamflow-gaging station East Canyon Creek near Jeremy Ranch, Utah, was $2.7 \mathrm{ft}^{3} / \mathrm{s}$, or a 19 percent gain. This study was conducted during a year with greater-than-average precipitation.

Brooks and others (1998) report a seepage loss in the area of Kimball Junction from measurements made by Downhour and Brooks (1996) in 1994 and 1995.

\section{Purpose and Scope}

Information on gains and losses to McLeod Creek and East Canyon Creek is needed by water managers in Snyderville Basin and the State of Utah in order to make decisions to 




Figure 1. Location of the study area, Park City, Snyderville Basin, and adjacent areas, Summit County, Utah. 


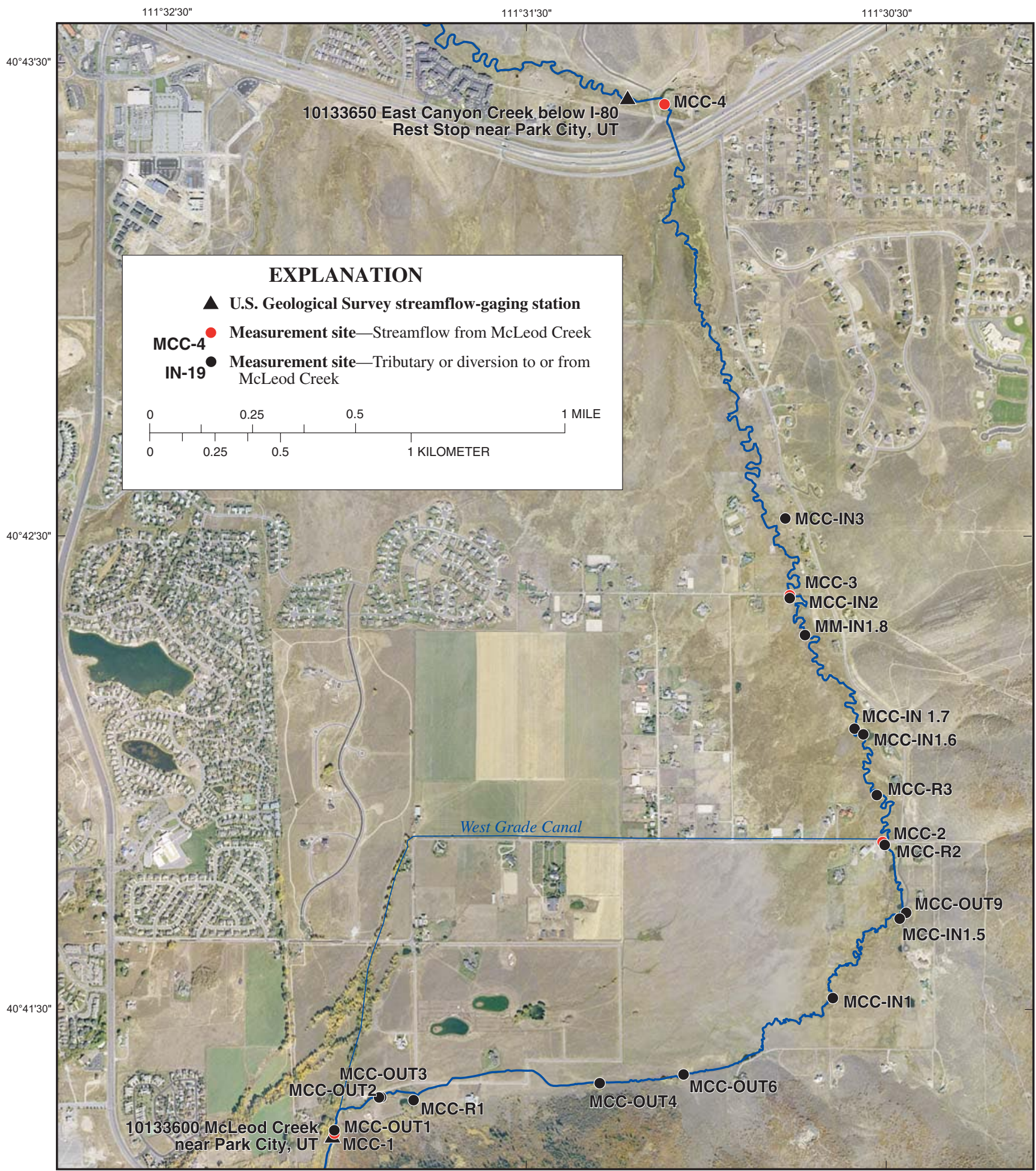

Figure 2. Location of the measurement sites along McLeod Creek near Park City, Utah. 


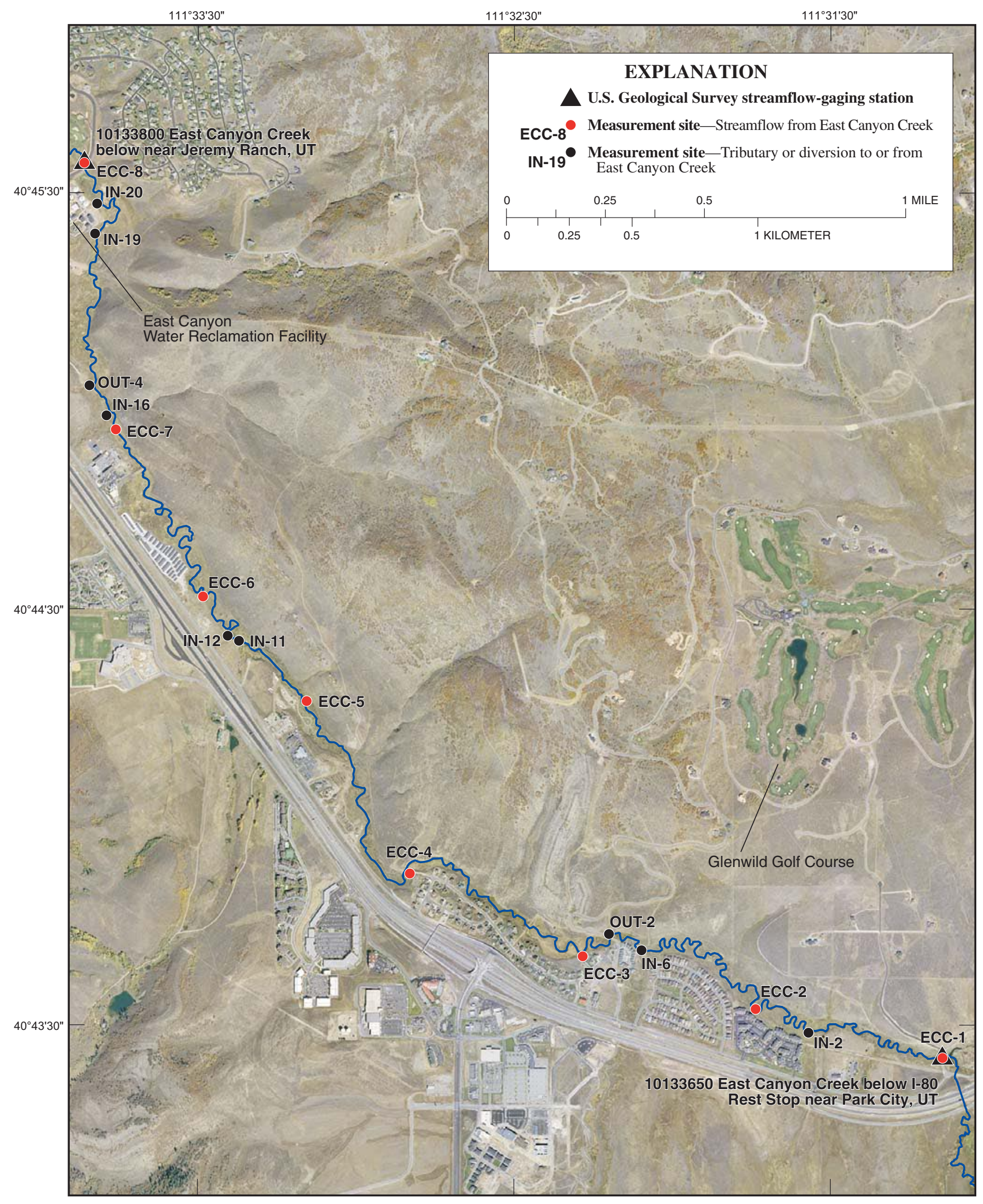

Figure 3. Location of the measurement sites along East Canyon Creek near Park City, Utah. 
improve water quality and fish habitat in the area. Therefore, a study was conducted by the USGS in cooperation with the Snyderville Basin Water Reclamation District during the summer of 2004. The results and interpretations from that study are presented in this report.

\section{Methods used to determine seepage along McLeod Creek and East Canyon Creek}

\section{Streamflow Measurements}

Discharge measurements were made using standard methods of the USGS (Buchanan and Somers, 1969). Measurement error using these methods is plus or minus 5 percent. For the measurements made on June 24, 2004, at the East Canyon Creek sites, a repeat discharge measurement was made at each site. In each case, the difference between the two measurements was less than 5 percent (table 1). Specific conductance, water temperature, $\mathrm{pH}$, and dissolved oxygen concentration were measured at selected sites on McLeod Creek and East Canyon Creek, and at each identified inflow along East Canyon Creek. Water-quality measurements were made either with a YSI 600QS multi-parameter meter, a Hydrolab Quanta, or a Hydrolab MiniSonde that were calibrated according to standard USGS procedures (Wilde and Radtke, eds. [variously dated]). Descriptions of the measurement sites along McLeod Creek and East Canyon Creek with latitude and longitude are listed in table 2. During the initial reconnaissance of McLeod Creek and East Canyon Creek, a number of small inflows from seeps and springs, and outflows from small pumps, were noted. These small diversions were not observed to flow during any of the seepage measurements. These sites have not been included in this report.

Table 1. Discharge measurements made on June 24, 2004, at selected East Canyon Creek sites near Park City, Utah

[in cubic feet per second]

\begin{tabular}{rcccrr}
\hline Site & $\begin{array}{c}\text { First } \\
\text { measure- } \\
\text { ment }\end{array}$ & $\begin{array}{c}\text { Second } \\
\text { measure- } \\
\text { ment }\end{array}$ & $\begin{array}{c}\text { Mean } \\
\text { discharge }\end{array}$ & Range & $\begin{array}{c}\text { Percent } \\
\text { error }\end{array}$ \\
\hline ECC-1 & 10.3 & 10.3 & 10.3 & 0.0 & 0.0 \\
ECC-2 & 11.6 & 12.0 & 11.8 & .4 & 3.4 \\
ECC-3 & 10.6 & 10.1 & 10.4 & .5 & 4.8 \\
ECC-4 & 10.7 & 10.9 & 10.8 & .2 & 1.9 \\
ECC-5 & 9.41 & 9.42 & 9.42 & .01 & .1 \\
ECC-6 & 8.77 & 8.68 & 8.73 & .09 & 1.0 \\
ECC-7 & 8.97 & 8.74 & 8.86 & .23 & 2.6 \\
ECC-8 & 12.3 & 12.9 & 12.6 & .6 & 4.8 \\
\hline
\end{tabular}

Measurement sites along McLeod Creek are shown in figure 2. Sites along the creek were chosen at convenient measurement locations that were 1 to $2 \mathrm{mi}$ apart. Inflow and diversion measurements and estimates were made wherever an active tributary or canal was observed. Measurements were made on June 24, July 30, August 30, and October 1, 2004. For each set of seepage measurements, the date, time, discharge, specific conductance, water temperature, $\mathrm{pH}$, and dissolved oxygen concentration from selected measurement locations are listed in table 3. On June 24, measurements were made only in the main channel of McLeod Creek. No measurements were made at inflows or diversions on this date. Inflows at MCC-IN1.5, MCC-IN1.6, MCC-IN1.7, and MCCIN1.8 were not measured on July 30, 2004, but were estimated as $0.1 \mathrm{ft}^{3} / \mathrm{s}$. Inflows at MCC-IN1.6 and MCC-IN1.7 were not measured on August 30, 2004, and were estimated as $0.1 \mathrm{ft}^{3} / \mathrm{s}$. Irrigation return flow at MCC-R3 was measured only on October 1, 2004. Estimates for flow at this location were not made on the other measurement dates. There are a number of small pumps along McLeod Creek that are used for lawn irrigation. Only one of these pumps (MCC-OUT9) was pumping during the seepage measurements. Discharge from this pump was estimated.

Four sets of measurements also were made along East Canyon Creek during the summer of 2004. These measurements were made on June 24, July 30, August 30, and October 1, 2004. Measurement sites along East Canyon Creek are shown in figure 3 . These sites were chosen at convenient measuring locations approximately $1 \mathrm{mi}$ apart. Inflows and diversions were measured or estimated wherever active flow was observed. For a selected set of seepage measurements, the date, time, discharge, specific conductance, water temperature, $\mathrm{pH}$, and dissolved oxygen concentration from each measurement location are listed in table 4 . OUT- 2 is a pumping station that uses water from East Canyon Creek for irrigation of the Glenwild Golf Club. Discharge at this outflow was estimated for each set of measurements at $1.3 \mathrm{ft}^{3} / \mathrm{s}$ (John O'Connell, oral commun., 2004). Station OUT-4 is a diversion to the Summit Water Distribution Company's water-treatment facility. Any water diverted to this facility during the summer of 2004 was immediately returned to East Canyon Creek (Van Martin, oral commun., 2004). Flow from the East Canyon Water Reclamation Facility enters East Canyon Creek at IN-20. Flow at this site was obtained from discharge records provided by the Snyderville Basin Water Reclamation District (Neil Jones, written commun., 2004).

Seepage is considered to be any gain or loss to a stream that is not accounted for by surface-water diversions or inflows. In other words, it is the gain or loss that occurs along the bounding channel materials to or from the subsurface. This may be seepage to the ground-water system, or it may be flow into and out of streambed material. Seepage gains and losses along the reaches were calculated by subtracting the downstream discharge from the next discharge measured upstream, then adding in any diversions and subtracting the inflowing tributaries.

Streamflow changes were recorded at three USGS streamflow-gaging stations: 10133600 , McLeod Creek near Park City, Utah (fig. 2), 10133650, East Canyon Creek below 
Table 2. Latitude, longitude, and site description of seepage measurement sites on McLeod Creek and East Canyon Creek near Park City, Utah

[Latitude: degrees north, NAD83; Longitide: degrees north, NAD83]

\begin{tabular}{|c|c|c|c|}
\hline Site & Latitude & Longitude & Description \\
\hline \multicolumn{4}{|r|}{ East Canyon Creek Seepage Measurement Site } \\
\hline ECC-1 & 40.72360 & 111.51930 & USGS gage East Canyon Creek below I-80 Rest Stop near Park City, UT (10133650). \\
\hline $\mathrm{IN}-2$ & 40.72461 & 111.52611 & Cow Creek inflow from Swaner Nature Preserve. \\
\hline ECC-2 & 40.72570 & 111.52910 & East Canyon Creek measuring location just behind apartment buildings. \\
\hline IN-6 & 40.72791 & 111.53491 & Spring Creek inflow from Silver Springs in Swaner Nature Preserve. \\
\hline OUT-2 & 40.72856 & 111.53662 & Glenwild Golf Course diversion pump. \\
\hline ECC-3 & 40.72780 & 111.53820 & East Canyon Creek measuring location just downstream from park. \\
\hline ECC-4 & 40.73110 & 111.54730 & East Canyon Creek measuring site near railroad car bridge at the west end Pheasant Way. \\
\hline ECC-5 & 40.73802 & 111.55272 & East Canyon Creek measuring site near picnic area at Park City RV Park. \\
\hline $\mathrm{IN}-11$ & 40.74030 & 111.55611 & Inflow from Threemile Canyon. \\
\hline $\mathrm{IN}-12$ & 40.74051 & 111.55671 & Return flow from Threemile Canyon diversion. \\
\hline ECC-6 & 40.74220 & 111.55820 & East Canyon Creek measuring site located just east of Summit Self-Storage. \\
\hline ECC-7 & 40.74890 & 111.56280 & East Canyon Creek measuring site located behind Sticks and Stones Furniture. \\
\hline $\mathrm{IN}-16$ & 40.74941 & 111.56302 & Inflow from Twomile Canyon. \\
\hline OUT-4 & 40.75060 & 111.56392 & Diversion to Summit Water Distribution Company's water treatment plant. \\
\hline $\mathrm{IN}-19$ & 40.75660 & 111.56371 & Inflow from Toll Canyon. \\
\hline $\mathrm{IN}-20$ & 40.75781 & 111.56361 & Outflow from East Canyon Water Reclamation facility. \\
\hline ECC-8 & 40.75940 & 111.56450 & USGS gage East Canyon Creek near Jeremy Ranch, UT (10133800). \\
\hline \multicolumn{4}{|r|}{ McLeod Creek Seepage Measurement Site } \\
\hline$\overline{\mathrm{MCC}-1}$ & 40.68743 & 111.53389 & USGS gage McLeod Creek near Park City, UT (10133600). \\
\hline MCC-OUT1 & 40.68733 & 111.53389 & Diversion to West Grade Canal. \\
\hline MCC-OUT2 & 40.68861 & 111.53171 & Diversion to private pond. \\
\hline MCC-OUT3 & 40.68861 & 111.53181 & Diversion to irrigation ditch. \\
\hline MCC-R1 & 40.68851 & 111.53021 & Return flow from private pond \\
\hline MCC-OUT4 & 40.68911 & 111.52161 & Diversion to old irrigation ditch. \\
\hline MCC-OUT6 & 40.68941 & 111.51771 & Diversion to old irrigation ditch. \\
\hline MCC-IN1 & 40.69211 & 111.51081 & Small spring inflow. \\
\hline MCC-IN1.5 & 40.69491 & 111.50771 & Inflow from springs located south of Ranch Creek Subdivision. \\
\hline MCC-OUT9 & 40.69511 & 111.50741 & Small pump used for lawn irrigation in Ranch Creek Subdivision. \\
\hline MCC-R2 & 40.69751 & 111.50841 & Return flow from south side of Old Ranch Road. \\
\hline MCC-2 & 40.69761 & 111.50851 & McLeod Creek measuring site located on south side of sharp bend in Old Ranch Road. \\
\hline MCC-R3 & 40.69791 & 111.50851 & Return flow from West Grade Canal. \\
\hline MCC-IN1.6 & 40.70141 & 111.50941 & Inflow on east side of McLeod Creek from spring fed pond. \\
\hline MCC-IN1.7 & 40.70161 & 111.50981 & Inflow on west side of McLeod Creek from spring or irrigation return. \\
\hline MM-IN1.8 & 40.70491 & 111.51211 & Inflow from spring located about 0.5 mile west of McLeod Creek. \\
\hline MCC-IN2 & 40.70621 & 111.51281 & Inflow from spring or irrigation near MCC-2 just south of private road. \\
\hline MCC-3 & 40.70631 & 111.51281 & McLeod Creek measuring site located just south of private road. \\
\hline MCC-IN3 & 40.70901 & 111.51301 & Small spring inflow. \\
\hline MCC-4 & 40.72361 & 111.51861 & McLeod Creek measuring site located just upstream from Kimball Creek. \\
\hline
\end{tabular}


Table 3. Measurements of discharge, specific conductance, water temperature, $\mathrm{pH}$, and concentration of dissolved oxygen in water from McLeod Creek near Park City, Utah

[Site: See figure 2 for site location; MCC, main channel; OUT, stream diversion; R, irrigation return flow; IN, tributary inflow; e, estimated; - , no data available]

\begin{tabular}{|c|c|c|c|c|c|c|}
\hline Site & Time & $\begin{array}{l}\text { Discharge } \\
\text { (cubic feet } \\
\text { per second) }\end{array}$ & $\begin{array}{l}\text { Specific conductance } \\
\text { (microsiemens per } \\
\text { centimeter at } \\
25 \text { degrees Celsius) }\end{array}$ & $\begin{array}{c}\text { Water } \\
\text { temperature } \\
\text { (degrees } \\
\text { Celsius) }\end{array}$ & $\begin{array}{c}\text { pH } \\
\text { (standard } \\
\text { units) }\end{array}$ & $\begin{array}{c}\text { Dissolved } \\
\text { oxygen } \\
\text { (milligrams per } \\
\text { liter) }\end{array}$ \\
\hline \multicolumn{7}{|c|}{ June 24,2004} \\
\hline MCC-1 & 940 & 7.64 & - & - & - & - \\
\hline MCC-OUT1 & 1050 & 4.69 & - & - & - & - \\
\hline MCC-OUT2 & & - & - & - & - & - \\
\hline MCC-OUT3 & & - & - & - & - & - \\
\hline MCC-R1 & & - & - & - & - & - \\
\hline MCC-OUT4 & & - & - & - & - & - \\
\hline MCC-OUT6 & & - & - & - & - & - \\
\hline MCC-IN1 & & - & - & - & - & - \\
\hline MCC-IN1.5 & & - & - & - & - & - \\
\hline MCC-OUT9 & & - & - & - & - & - \\
\hline MCC-R2 & & - & - & - & - & - \\
\hline MCC-2 & 1135 & 2.55 & - & - & - & - \\
\hline MCC-R3 & & - & - & - & - & - \\
\hline MCC-IN1.6 & & - & - & - & - & - \\
\hline MCC-IN1.7 & & - & - & - & - & - \\
\hline MCC-IN1.8 & & - & - & - & - & - \\
\hline MCC-IN2 & & - & - & - & - & - \\
\hline MCC-3 & 1235 & 7.79 & - & - & - & - \\
\hline MCC-IN3 & & - & - & - & - & - \\
\hline MCC-4 & 1435 & 9.05 & - & - & - & - \\
\hline \multicolumn{7}{|c|}{ July 30, 2004} \\
\hline MCC-1 & 1016 & 4.85 & 708 & 13.4 & 7.4 & 9.0 \\
\hline MCC-OUT1 & 1134 & 3.40 & - & - & - & - \\
\hline MCC-OUT2 & 1030 & .90 & - & - & - & - \\
\hline MCC-OUT3 & 1055 & .57 & - & - & - & - \\
\hline MCC-R1 & 1111 & .82 & - & - & - & - \\
\hline MCC-OUT4 & 1145 & .22 & - & - & - & - \\
\hline MCC-OUT6 & 1205 & .13 & - & - & - & - \\
\hline MCC-IN1 & 1235 & .03 & - & - & - & - \\
\hline MCC-IN1.5 & & $.1 \mathrm{e}$ & - & - & - & - \\
\hline MCC-OUT9 & 1250 & $.1 \mathrm{e}$ & - & - & - & - \\
\hline MCC-R2 & 1226 & .40 & - & - & - & - \\
\hline MCC-2 & 1158 & 1.11 & 793 & 15.7 & 7.2 & 8.5 \\
\hline MCC-R3 & & - & - & - & - & - \\
\hline MCC-IN1.6 & & $.1 \mathrm{e}$ & - & - & - & - \\
\hline MCC-IN1.7 & & $.1 \mathrm{e}$ & - & - & - & - \\
\hline MCC-IN1.8 & & $.1 \mathrm{e}$ & - & - & - & - \\
\hline MCC-IN2 & 1350 & .05 & - & - & - & - \\
\hline MCC-3 & 1328 & 2.60 & 758 & 21.3 & 8.0 & - \\
\hline MCC-IN3 & & $.1 \mathrm{e}$ & - & - & - & - \\
\hline MCC-4 & 1426 & 4.01 & 800 & 19.2 & 8.0 & 10.5 \\
\hline
\end{tabular}


Table 3. Measurements of discharge, specific conductance, water temperature, $\mathrm{pH}$, and concentration of dissolved oxygen in water from McLeod Creek near Park City, Utah—Continued

\begin{tabular}{|c|c|c|c|c|c|c|}
\hline Site & Time & $\begin{array}{l}\text { Discharge } \\
\text { (cubic feet } \\
\text { per second) }\end{array}$ & $\begin{array}{l}\text { Specific conductance } \\
\text { (microsiemens per } \\
\text { centimeter at } \\
25 \text { degrees Celsius) }\end{array}$ & $\begin{array}{c}\text { Water } \\
\text { temperature } \\
\text { (degrees } \\
\text { Celsius) }\end{array}$ & $\begin{array}{c}\mathrm{pH} \\
\text { (standard } \\
\text { units) }\end{array}$ & $\begin{array}{c}\text { Dissolved } \\
\text { oxygen } \\
\text { (milligrams per } \\
\text { liter) }\end{array}$ \\
\hline \multicolumn{7}{|c|}{ August 30,2004} \\
\hline MCC-1 & 1050 & 4.84 & 736 & 12.4 & 8.0 & - \\
\hline MCC-OUT1 & 1130 & 3.13 & - & - & - & - \\
\hline MCC-OUT2 & 1049 & .85 & - & - & - & - \\
\hline MCC-OUT3 & 1111 & .18 & - & - & - & - \\
\hline MCC-R1 & 1138 & .09 & - & - & - & - \\
\hline MCC-OUT4 & 1200 & $.01 \mathrm{e}$ & - & - & - & - \\
\hline MCC-OUT6 & 1227 & .02 & - & - & - & - \\
\hline MCC-IN1 & 1254 & .00 & - & - & - & - \\
\hline MCC-IN1.5 & 1329 & .19 & - & - & - & - \\
\hline MCC-OUT9 & 1342 & $.01 \mathrm{e}$ & - & - & - & - \\
\hline MCC-R2 & 1230 & .22 & 870 & 10.8 & 7.1 & 6.8 \\
\hline MCC-2 & 1300 & 1.06 & 748 & 13.7 & 7.8 & 9.0 \\
\hline MCC-R3 & & - & - & - & - & - \\
\hline MCC-IN1.6 & & $.1 \mathrm{e}$ & - & - & - & - \\
\hline MCC-IN1.7 & & $.1 \mathrm{e}$ & - & - & - & - \\
\hline MCC-IN1.8 & 1515 & .09 & - & - & - & - \\
\hline MCC-IN2 & 1355 & .00 & - & - & - & - \\
\hline MCC-3 & 1415 & 2.67 & 728 & 17.6 & 8.6 & 12.9 \\
\hline MCC-IN3 & 1410 & $.01 \mathrm{e}$ & - & - & - & - \\
\hline MCC-4 & 1445 & 3.41 & 790 & 15 & 8.4 & 11.0 \\
\hline \multicolumn{7}{|c|}{ October 1, 2004} \\
\hline MCC-1 & 900 & 5.52 & 710 & 7.5 & 7.7 & 9.1 \\
\hline MCC-OUT1 & 938 & 3.42 & - & - & - & - \\
\hline MCC-OUT2 & 923 & .67 & - & - & - & - \\
\hline MCC-OUT3 & 942 & .90 & - & - & - & - \\
\hline MCC-R1 & 954 & .29 & - & - & - & - \\
\hline MCC-OUT4 & 1021 & .04 & - & - & - & - \\
\hline MCC-OUT6 & 1037 & .39 & - & - & - & - \\
\hline MCC-IN1 & 1100 & .00 & - & - & - & - \\
\hline MCC-IN1.5 & 1138 & .11 & - & - & - & - \\
\hline MCC-OUT9 & 1125 & .00 & - & - & - & - \\
\hline MCC-R2 & 1045 & .19 & 820 & 8.3 & 7.5 & 9.7 \\
\hline MCC-2 & 1050 & .96 & 700 & 9.2 & 7.5 & 7.5 \\
\hline MCC-R3 & 1135 & 2.26 & 690 & 9.2 & 8.3 & 10.0 \\
\hline MCC-IN1.6 & 1214 & .05 & 810 & 12.8 & 7.8 & 6.2 \\
\hline MCC-IN1.7 & 1230 & $.1 \mathrm{e}$ & 800 & 9.8 & 7.6 & 8 \\
\hline MCC-IN1.8 & 1316 & .25 & - & - & - & - \\
\hline MCC-IN2 & 1150 & .00 & - & - & - & - \\
\hline MCC-3 & 1150 & 4.40 & 710 & 9.7 & 8.0 & 14.1 \\
\hline MCC-IN3 & 1350 & .00 & - & - & - & - \\
\hline MCC-4 & 1245 & 5.15 & 740 & 8.5 & 7.8 & 11.1 \\
\hline
\end{tabular}


Table 4. Measurements of discharge, specific conductance, water temperature, $\mathrm{pH}$, and concentration of dissolved oxygen in water from East Canyon Creek near Park City, Utah

[Site: See figure 3 for site location; ECC, main channel; IN, tributary inflow; OUT, stream diversion; e, estimated; - , no data available]

\begin{tabular}{|c|c|c|c|c|c|}
\hline Site & Time & $\begin{array}{l}\text { Discharge } \\
\text { (cubic feet } \\
\text { per second) }\end{array}$ & $\begin{array}{c}\text { Water } \\
\text { temperature } \\
\text { (degrees } \\
\text { Celsius) }\end{array}$ & $\begin{array}{c}\text { pH } \\
\text { (Standard } \\
\text { units) }\end{array}$ & $\begin{array}{l}\text { Dissolved- } \\
\text { oxygen } \\
\text { (milligrams } \\
\text { per liter) }\end{array}$ \\
\hline \multicolumn{6}{|c|}{ June 24, 2004} \\
\hline ECC-1 & 930 & ${ }^{1} 10.30$ & 20.7 & 8.1 & 12.6 \\
\hline IN-2 & 1004 & 1.13 & 10.7 & 7.1 & 5.7 \\
\hline ECC-2 & 1110 & ${ }^{1} 11.80$ & 14.0 & 8.1 & 9.4 \\
\hline IN-6 & 1051 & 1.97 & 15.1 & 8.0 & 8.6 \\
\hline OUT-2 & & $1.3 \mathrm{e}$ & - & - & - \\
\hline ECC-3 & 1232 & ${ }^{1} 10.35$ & 16.0 & 8.5 & 10.5 \\
\hline ECC-4 & 1356 & ${ }^{1} 10.80$ & 17.1 & 8.4 & 13.6 \\
\hline ECC-5 & 940 & 19.42 & 20.2 & 8.4 & 10.9 \\
\hline IN-11 & 1209 & 1.27 & 17.8 & 8.2 & 10.9 \\
\hline IN-12 & 1236 & 1.08 & 19.9 & 8.3 & 9.1 \\
\hline ECC-6 & 1115 & ${ }^{1} 8.73$ & 20.3 & 8.5 & 11.7 \\
\hline ECC-7 & 1250 & ${ }^{1} 8.86$ & 20.5 & 8.5 & - \\
\hline IN-16 & 1341 & 1.01 & 19.6 & 7.6 & - \\
\hline IN-19 & 1435 & 1.97 & 20.5 & 8 & - \\
\hline IN-20 & 1330 & ${ }^{1} 3.10$ & 17.3 & 7.7 & 12.8 \\
\hline ECC-8 & 1409 & ${ }^{1} 12.60$ & 20.9 & 8.6 & 10.3 \\
\hline \multicolumn{6}{|c|}{ July 30, 2004} \\
\hline ECC-1 & 952 & 4.81 & 14.8 & 7.9 & 8.8 \\
\hline $\mathrm{IN}-2$ & 1102 & .15 & 12.0 & 7.1 & 5.8 \\
\hline ECC-2 & 1150 & 4.29 & 19.3 & 8.5 & 12.5 \\
\hline IN-6 & 1243 & .24 & 18.2 & 8.2 & 11.7 \\
\hline OUT-2 & & $1.3 \mathrm{e}$ & - & - & - \\
\hline ECC-3 & 1313 & 3.20 & 21.2 & 8.7 & 12.2 \\
\hline ECC-4 & 1420 & 2.84 & 22.0 & 8.5 & 9.8 \\
\hline ECC-5 & 1005 & 2.54 & 17.2 & 7.7 & 9.6 \\
\hline IN-11 & 1055 & .18 & 15.4 & 7.3 & 6.8 \\
\hline IN-12 & 1110 & .00 & - & - & - \\
\hline ECC-6 & 1125 & 2.97 & 18.8 & 7.8 & 10.6 \\
\hline ECC-7 & 1225 & 2.75 & 20.5 & 8.0 & 10.6 \\
\hline IN-16 & 1305 & .01 & 17.4 & 7.7 & 10.1 \\
\hline IN-19 & 1350 & .74 & 20.4 & 8.0 & 9.6 \\
\hline IN-20 & 1300 & 3.60 & - & - & - \\
\hline ECC-8 & 1425 & 7.15 & 22.2 & 8.2 & 11.0 \\
\hline \multicolumn{6}{|c|}{ August 30, 2004} \\
\hline ECC-1 & 1030 & 3.58 & 11.8 & 8.0 & 9.5 \\
\hline IN-2 & 1200 & .03 & 11.8 & 7.1 & 5.3 \\
\hline ECC-2 & 1300 & 3.69 & 18.4 & 8.5 & 12.2 \\
\hline IN-6 & 1358 & .18 & 16.0 & 8.1 & 10.8 \\
\hline OUT-2 & & $1.3 \mathrm{e}$ & - & - & - \\
\hline ECC-3 & 1443 & 2.20 & 19.6 & 8.7 & 12.6 \\
\hline ECC-4 & 1534 & 2.55 & 18.4 & 8.4 & 9.6 \\
\hline ECC-5 & 1040 & 2.72 & 15.3 & 8.1 & 13.2 \\
\hline IN-11 & 1245 & .06 & 14.6 & 7.4 & 7.5 \\
\hline IN-12 & 1230 & .00 & - & - & - \\
\hline ECC-6 & 1157 & 3.41 & 15.4 & 8.0 & 12.6 \\
\hline ECC-7 & 1430 & 3.61 & 19.1 & 8.3 & 11.3 \\
\hline IN-16 & 1405 & .01 & 16.7 & 7.8 & 12.2 \\
\hline IN-19 & 1520 & .47 & 17.9 & 8 & 9.0 \\
\hline IN-20 & 1530 & 3.60 & - & - & - \\
\hline ECC-8 & 1554 & 6.90 & 20.2 & 8.1 & 10.7 \\
\hline
\end{tabular}


Table 4. Measurements of discharge, specific conductance, water temperature, $\mathrm{pH}$, and concentration of dissolved oxygen in water from East Canyon Creek near Park City, Utah—Continued

\begin{tabular}{|c|c|c|c|c|c|}
\hline Site & Time & $\begin{array}{c}\text { Discharge } \\
\text { (cubic feet } \\
\text { per second) }\end{array}$ & $\begin{array}{c}\text { Water } \\
\text { temperature } \\
\text { (degrees } \\
\text { Celsius) } \\
\end{array}$ & $\begin{array}{c}\mathrm{pH} \\
\text { (Standard } \\
\text { units) }\end{array}$ & $\begin{array}{c}\text { Dissolved- } \\
\text { oxygen } \\
\text { (milligrams } \\
\text { per liter) }\end{array}$ \\
\hline \multicolumn{6}{|c|}{ October 1, 2004} \\
\hline ECC-1 & 840 & 6.69 & 6.6 & 7.6 & 9.1 \\
\hline $\mathrm{IN}-2$ & 950 & .09 & 9.2 & 7.4 & 7.2 \\
\hline ECC-2 & 1023 & 6.00 & 7.6 & 8.1 & 10.7 \\
\hline IN-6 & 1107 & .12 & 8.0 & 8.1 & 11.6 \\
\hline OUT-2 & & $1.3 \mathrm{e}$ & - & - & - \\
\hline ECC-3 & 1130 & 4.80 & 9.2 & 8.4 & 11.8 \\
\hline ECC-4 & 1226 & 4.31 & 8.9 & 8.3 & 10.6 \\
\hline ECC-5 & 915 & 4.71 & 7.2 & 8.0 & 10.1 \\
\hline $\mathrm{IN}-11$ & 1010 & .02 & 9.0 & 7.0 & 5.9 \\
\hline $\mathrm{IN}-12$ & 1035 & .00 & - & - & - \\
\hline ECC-6 & 1040 & 4.42 & 8.0 & 8.0 & 10.4 \\
\hline ECC-7 & 1200 & 4.77 & 10.4 & 8.3 & 11.2 \\
\hline $\mathrm{IN}-16$ & 1140 & .01 & 8.6 & 7.7 & 9.5 \\
\hline $\mathrm{IN}-19$ & 1308 & .31 & 10.8 & 8.3 & 10.8 \\
\hline $\mathrm{IN}-20$ & 1430 & 3.20 & 16.4 & 7.3 & 8.0 \\
\hline ECC-8 & 1343 & 7.94 & 14.7 & 8.2 & 11.3 \\
\hline
\end{tabular}

${ }^{1}$ Average of two discharge measurements.

I-80 Rest Stop near Park City, Utah (figs. 2, 3), and 10133800, East Canyon Creek near Jeremy Ranch, Utah (fig. 3). Discharge records from the three streamflow-gaging stations are shown in figures 4, 5, and 6, respectively. Because McLeod, Kimball, and East Canyon Creeks are in large part unregulated streams, small changes in discharge occurred during the course of most series of measurements. Recorded discharge at the beginning and end of the seepage measurements at each of the streamflow-gaging stations is shown in table 5. Changes in recorded discharge at the McLeod Creek near Park City gage ranged from -0.6 to $0.3 \mathrm{ft}^{3} / \mathrm{s}$. Changes in recorded discharge at the East Canyon Creek below I-80 Rest Stop near Park City gage ranged from -0.2 to $-0.7 \mathrm{ft}^{3} / \mathrm{s}$. Changes in recorded discharge at the East Canyon Creek near Jeremy Ranch gage ranged from -3.1 to $0.2 \mathrm{ft}^{3} / \mathrm{s}$. The large change in discharge at the Jeremy Ranch site occurred on October 1, 2004. Only about $0.5 \mathrm{ft}^{3} / \mathrm{s}$ of the $-3.1 \mathrm{ft}^{3} / \mathrm{s}$ change can be attributed to changing flow from the East Canyon Reclamation facility (Neil Jones, written commun., 2004). A $-0.5 \mathrm{ft}^{3} / \mathrm{s}$ change in discharge was recorded at the upstream station East Canyon Creek below I-80 Rest Stop on the same date (table 5). The other $-2.1 \mathrm{ft}^{3} / \mathrm{s}$ change observed at the downstream station may have been caused by the Glenwild Golf Club pump (OUT-2) turning on. The change in discharge at the Jeremy Ranch gaging station started at about 11:00 a.m. on October 1. The travel time from OUT-2 to Jeremy Ranch is unknown but is most likely on the order of a few hours. Therefore, it is likely that the pump was switched on sometime prior to the start of measurements on October 1, 2004. A plot of discharge measured along East Canyon Creek for each of the measurement dates shows that the measurements made on October 1, 2004, follow a similar downstream trend as the previous measurements (fig. 7). This indicates that discharge in the creek had stabilized by the time the seepage measurements were made.

When evaluating seepage values, natural streamflow fluctuations need to be considered. Recorded discharge at the three streamflow-gaging stations varied at a constant rate of change during most seepage measurements. Therefore, a rate of change in discharge per hour is also calculated in table 5 . The rate of change multiplied by the amount of time between measurements is used as an estimate of the amount of discharge change attributed to natural streamflow fluctuations. For example, the rate of change recorded at East Canyon Creek below I-80 Rest Stop near Park City, Utah, on June 24, 2004, was $-0.1 \mathrm{ft}^{3} / \mathrm{s}$ per hour. This value was then multiplied by the amount of time between measurements at ECC-1 and ECC-2 (1.7 hours) to get an estimated change in flow of -0.2 $\mathrm{ft}^{3} / \mathrm{s}$. These calculations and estimates are shown in table 6 for McLeod Creek and in table 7 for East Canyon Creek. Seepage calculations in the range of these estimates should be considered beyond the limit of measurable gains or losses using traditional discharge measurement techniques. 


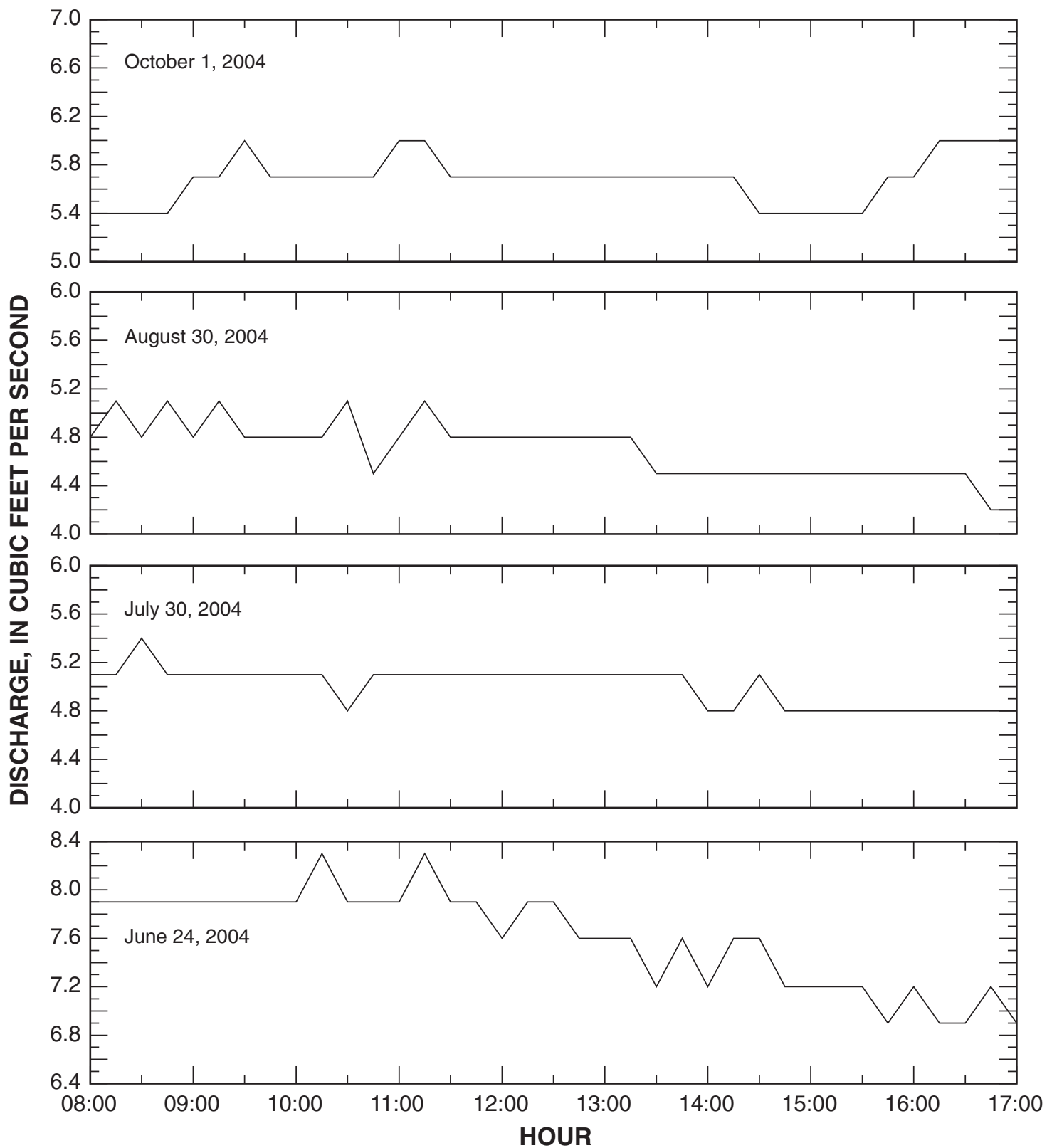

Figure 4. Discharge at U.S. Geological Survey streamflow-gaging station McLeod Creek near Park City, Utah. 


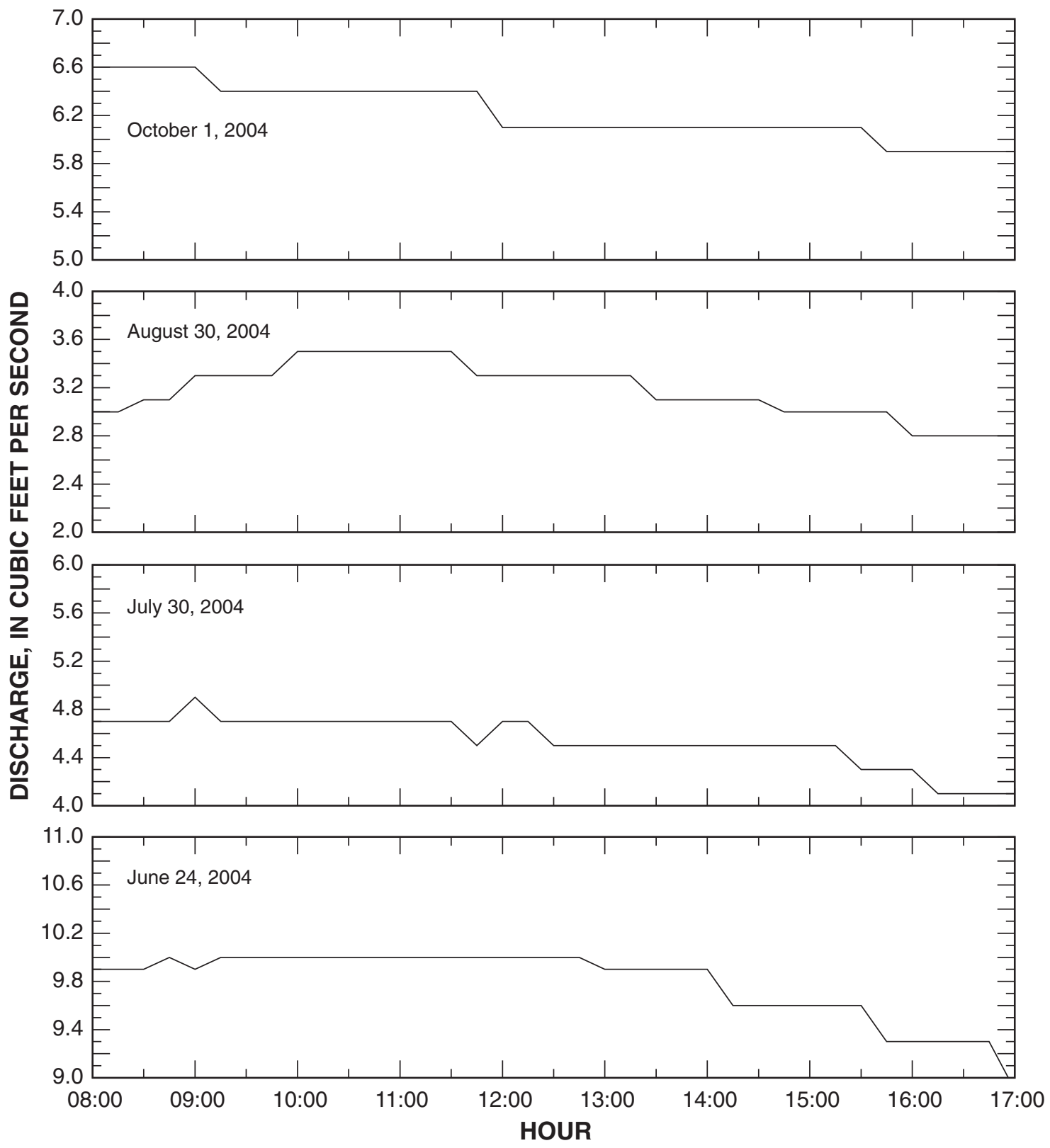

Figure 5. Discharge at U.S. Geological Survey streamflow-gaging station East Canyon Creek below I-80 Rest Stop near Park City, Utah. 



Figure 6. Discharge at U.S. Geological Survey streamflow-gaging station East Canyon Creek near Jeremy Ranch, Utah. 
Table 5. Difference in recorded discharge at streamflow-gaging stations on McLeod and East Canyon Creeks near Park City, Utah

\begin{tabular}{|c|c|c|c|c|c|c|c|c|}
\hline & \multicolumn{2}{|c|}{ June 24, 2004} & \multicolumn{2}{|c|}{ July 30, 2004} & \multicolumn{2}{|c|}{ August 30, 2004} & \multicolumn{2}{|c|}{ October 1, 2004} \\
\hline & $\begin{array}{l}\text { Discharge } \\
\text { (cubic feet } \\
\text { per second) }\end{array}$ & Time & $\begin{array}{l}\text { Discharge } \\
\text { (cubic feet } \\
\text { per second) }\end{array}$ & Time & $\begin{array}{l}\text { Discharge } \\
\text { (cubic feet } \\
\text { per second) }\end{array}$ & Time & $\begin{array}{l}\text { Discharge } \\
\text { (cubic feet } \\
\text { per second) }\end{array}$ & Time \\
\hline \multicolumn{9}{|c|}{ McLeod Creek near Park City, Utah } \\
\hline Starting discharge & 7.9 & 0930 & 5.1 & 0950 & 5.1 & 1030 & 5.4 & 0840 \\
\hline Change in discharge per hour & -.1 & & .0 & & -.1 & & .1 & \\
\hline \multicolumn{9}{|c|}{ East Canyon Creek below I-80 Rest Stop near Park City, Utah } \\
\hline Starting discharge & 10.0 & 0930 & 4.7 & 0930 & 3.5 & 1030 & 6.6 & 0840 \\
\hline Ending discharge & 9.6 & 1410 & 4.5 & 1410 & 2.8 & 1600 & 6.1 & 1340 \\
\hline Ending discharge & 13.0 & 1410 & 7.2 & 1410 & 6.9 & 1600 & 7.9 & 1340 \\
\hline Change in discharge & .0 & & -.5 & & .2 & & -3.1 & \\
\hline Change in discharge per hour & .0 & & -.1 & & .0 & & -.6 & \\
\hline
\end{tabular}

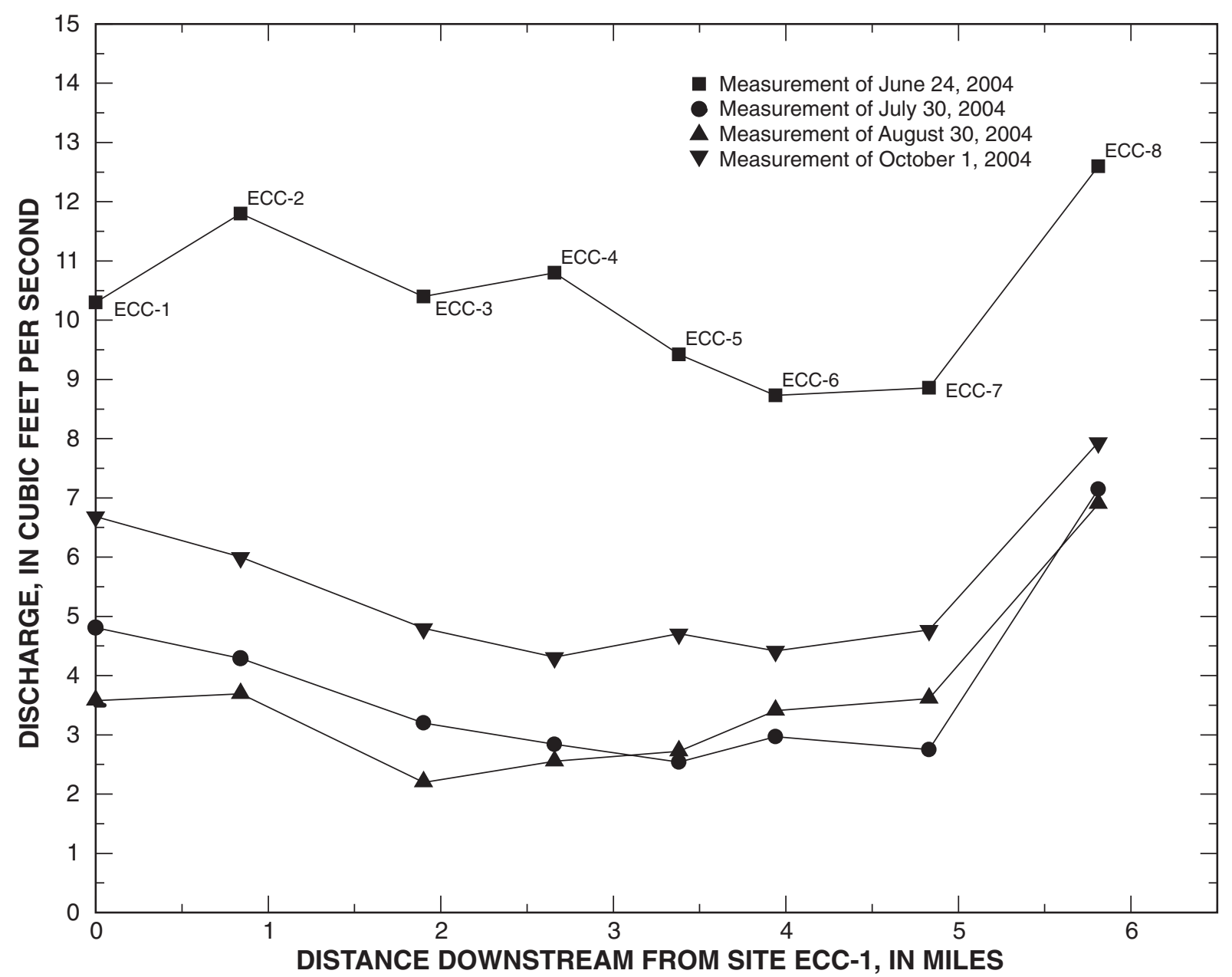

Figure 7. Discharge along East Canyon Creek near Park City, Utah. 
Table 6. Estimated discharge fluctuation during seepage measurements on McLeod Creek near Park City, Utah

[Rate of change calculated in table 5 from McLeod Creek near Park City, $\underline{\text { Utah] }}$

\begin{tabular}{|c|c|c|c|}
\hline Reach & $\begin{array}{c}\text { Time } \\
\text { between } \\
\text { measurements } \\
\text { (hours) }\end{array}$ & $\begin{array}{l}\text { Rate of } \\
\text { change in } \\
\text { discharge } \\
\text { (cubic feet per } \\
\text { second per } \\
\text { hour) }\end{array}$ & $\begin{array}{l}\text { Estimated } \\
\text { natural } \\
\text { discharge } \\
\text { change } \\
\text { (cubic feet } \\
\text { per second) }\end{array}$ \\
\hline \multicolumn{4}{|c|}{ June 24, 2004} \\
\hline$\overline{\mathrm{MCC}-1 \text { to } \mathrm{MCC}-2}$ & 0.8 & -0.1 & -0.1 \\
\hline MCC-2 to MCC-3 & 1.0 & -.1 & -.1 \\
\hline MCC-3 to MCC-4 & 2.0 & -.1 & -.2 \\
\hline \multicolumn{4}{|c|}{ July 30, 2004} \\
\hline$\overline{\mathrm{MCC}}-1$ to $\mathrm{MCC}-2$ & 1.7 & .0 & .0 \\
\hline MCC-2 to MCC-3 & 1.5 & .0 & .0 \\
\hline MCC-3 to MCC-4 & .6 & .0 & .0 \\
\hline \multicolumn{4}{|c|}{ August 30, 2004} \\
\hline$\overline{\mathrm{MCC}}-1$ to $\mathrm{MCC}-2$ & 2.2 & -.1 & -.2 \\
\hline MCC-2 to MCC-3 & 1.2 & -.1 & -.1 \\
\hline MCC-3 to MCC-4 & .5 & -.1 & -.1 \\
\hline \multicolumn{4}{|c|}{ October 1, 2004} \\
\hline$\overline{\mathrm{MCC}}-1$ to $\mathrm{MCC}-2$ & 1.8 & .1 & .2 \\
\hline $\mathrm{MCC}-2$ to $\mathrm{MCC}-3$ & 1.0 & .1 & .1 \\
\hline $\mathrm{MCC}-3$ to $\mathrm{MCC}-4$ & .9 & .1 & .1 \\
\hline
\end{tabular}

Table 7. Estimated discharge fluctuation during seepage measurements on East Canyon Creek near Park City, Utah

[Rate of change calculated in table 5 from East Canyon Creek below I-80 Rest Stop near Park City, Utah]

\begin{tabular}{|c|c|c|c|}
\hline Reach & $\begin{array}{c}\text { Time between } \\
\text { measurements } \\
\text { (hours) }\end{array}$ & $\begin{array}{c}\text { Rate of } \\
\text { change in } \\
\text { discharge } \\
\text { (cubic feet } \\
\text { per second } \\
\text { per hour) }\end{array}$ & $\begin{array}{l}\text { Estimated } \\
\text { natural } \\
\text { discharge } \\
\text { change } \\
\text { (cubic feet per } \\
\text { second) }\end{array}$ \\
\hline \multicolumn{4}{|c|}{ June 24, 2004} \\
\hline$\overline{\text { ECC-1 TO ECC-2 }}$ & 1.7 & -.1 & -0.2 \\
\hline ECC-2 TO ECC-3 & 1.4 & -.1 & -.1 \\
\hline ECC-3 TO ECC-4 & 1.4 & -.1 & -.1 \\
\hline ECC-4 TO ECC-5 & 2.3 & -.1 & -.2 \\
\hline ECC-5 TO ECC-6 & 1.6 & -.1 & -.2 \\
\hline ECC-6 TO ECC-7 & 1.6 & -.1 & -.2 \\
\hline ECC-7 TO ECC-8 & 1.3 & -.1 & -.1 \\
\hline \multicolumn{4}{|c|}{ July 30, 2004} \\
\hline$\overline{\text { ECC-1 TO ECC-2 }}$ & 2.0 & .0 & .0 \\
\hline ECC-2 TO ECC-3 & 1.4 & .0 & .0 \\
\hline ECC-3 TO ECC-4 & 1.1 & .0 & .0 \\
\hline ECC-4 TO ECC-5 & 4.2 & .0 & .0 \\
\hline ECC-5 TO ECC-6 & 1.3 & .0 & .0 \\
\hline ECC-6 TO ECC-7 & 1.0 & .0 & .0 \\
\hline ECC-7 TO ECC-8 & 2.0 & .0 & .0 \\
\hline \multicolumn{4}{|c|}{ August 30, 2004} \\
\hline$\overline{\text { ECC-1 TO ECC-2 }}$ & 1.5 & -.1 & -.2 \\
\hline ECC-2 TO ECC-3 & 1.7 & -.1 & -.2 \\
\hline ECC-3 TO ECC-4 & .8 & -.1 & -.1 \\
\hline ECC-4 TO ECC-5 & 2.2 & -.1 & -.2 \\
\hline ECC-5 TO ECC-6 & 1.3 & -.1 & -.1 \\
\hline ECC-6 TO ECC-7 & 2.6 & -.1 & -.3 \\
\hline ECC-7 TO ECC-8 & 1.4 & -.1 & -.1 \\
\hline \multicolumn{4}{|c|}{ October 1, 2004} \\
\hline$\overline{\text { ECC-1 TO ECC-2 }}$ & 1.7 & -.1 & -.2 \\
\hline ECC-2 TO ECC-3 & 1.1 & -.1 & -.1 \\
\hline ECC-3 TO ECC-4 & .9 & -.1 & -.1 \\
\hline ECC-4 TO ECC-5 & 3.2 & -.1 & -0.3 \\
\hline ECC-5 TO ECC-6 & 1.4 & -.1 & -.1 \\
\hline ECC-6 TO ECC-7 & 1.3 & -.1 & -.1 \\
\hline ECC-7 TO ECC-8 & 1.7 & -.1 & -.2 \\
\hline
\end{tabular}




\section{Temperature Measurements in East Canyon Creek}

Stonestrom and Constantz (2003) have shown that heat can be used as a tracer to track the movement of water from a stream into the subsurface. With this method, heat flow is observed by monitoring the water temperature in the surface water and in a piezometer that is installed in the streambed material. In a losing stream, the downward flow of water transports heat into the sediments underlying the stream. The heat transfer can be observed if the diurnal temperature variation in the surface water is large compared to the diurnal temperature variation in the underlying sediment. This is generally the case for most natural streams. If no transfer of the temperature variation is observed, this indicates that water is not moving downward into the sediments, but rather, may be moving upwards into the stream. A stream reach with this type of signature is a gaining reach (Stonestrom and Constantz, 2003).

To determine if the study reach of East Canyon Creek is a gaining or losing reach, three shallow piezometers were installed in the creek bed to measure temperature fluctuations in the stream and in the streambed material. A well was installed at sites ECC-2, ECC-4, and ECC-7. The piezometers consisted of a 2 -in. steel pipe that was flattened to a point on one end and driven approximately 1 to $2 \mathrm{ft}$ into the streambed. The bottom of the pipe was perforated to allow water in the bed material to enter the well. Two Tidbit@ temperature loggers were installed at each location. One was installed inside and at the bottom of the well while the other was attached to the outside of the pipe to record the surface-water temperature. A photo of a piezometer installation is shown in figure 8. Water-temperature data were collected from July 12 to October 29, 2004.

\section{Results and Discussion}

\section{Seepage gains and losses for McLeod Creek}

Four measurement sites along McLeod Creek were selected to evaluate seepage gains and losses. For the first set of measurements on June 24, 2004, measurements were made only in the main channel of McLeod Creek. No measurements were made at inflows or diversions. Therefore, the values for this date only reflect changes in discharge along the creek and are not considered to be seepage values. Values from June 24, 2004, were not used to evaluate apparent seepage gains and losses for each reach. They are included in this analysis as a comparison to the other seepage calculations. The calculated gain or loss for each series of measurements and the apparent average gain or loss calculated from the measurements made on July 30, August 30, and October 1, 2004, for McLeod Creek are reported in table 8 . Total gain or loss is also shown as a percentage of the flow measured at site MCC-1. The measured seepage and the apparent average seepage are shown as a function of distance along the creek in figure 9.

On June 24, 2004, the loss in discharge from sites MCC1 to $\mathrm{MCC}-2$ was $-5.1 \mathrm{ft}^{3} / \mathrm{s}$. This loss is the likely result of water that is diverted for irrigation at the West Grade Canal (MCC-OUT1). It appears that much of this water is returned in the next downstream reach. Reach MCC-1 to MCC-2 showed no consistent gain or loss for the other measurement dates (fig. 9). The calculated seepage ranged from $-0.1 \mathrm{ft}^{3} / \mathrm{s}$ on August 30, 2004, to $0.3 \mathrm{ft}^{3} / \mathrm{s}$ on October 1, 2004. These values are within the range of the discharge measurement error. The apparent average seepage loss for the reach was $0.1 \mathrm{ft}^{3} / \mathrm{s}$ or about $0.0 \mathrm{ft}^{3} / \mathrm{s} / \mathrm{mi}$ (table 8 ). These values are also within the range of measurement error.

Reach MCC-2 to MCC-3 showed a consistent net gain for all measurement dates (fig. 9). The net gain in discharge from site MCC-2 to MCC-3 on June 24, 2004, was $5.2 \mathrm{ft}^{3} / \mathrm{s}$. A substantial part of this gain is irrigation return water from the West Grade Canal. The greatest seepage gains occurred during the measurements in July and August. MCC-R3 is a major irrigation return from water diverted at MCC-OUT1 (West Grade Canal). However, until the last measurement run of the study, it was believed that this return was located at MCC-R2. Therefore, MCC-R3 was not measured until October 1, 2004. Seepage gains reported in the reach from MCC-2 to MCC-3 include surface water that is returned from this diversion. It is likely, however, that most of the water diverted during the July and August measurements was consumed for irrigation, and the amount of water returned at MCC-R3 on July 30 and August 30, 2004, was small. For this reach the value measured on October 1, 2004, $0.8 \mathrm{ft}^{3} / \mathrm{s}$, is the most representative of actual seepage. Seepage in this reach ranged from 0.8 to $1.3 \mathrm{ft}^{3} / \mathrm{s}$. The apparent average gain was $1.1 \mathrm{ft}^{3} / \mathrm{s}$ or $0.9 \mathrm{ft}^{3} / \mathrm{s} / \mathrm{mi}$ gain (table 8 ).

Reach MCC-3 to MCC-4 also showed a consistent seepage gain for all measurements (fig. 9). Seepage in this reach ranged from 0.7 to $1.3 \mathrm{ft}^{3} / \mathrm{s}$. The difference in discharge between MCC-3 and MCC-4 measured on June 24, 2004, was $1.3 \mathrm{ft}^{3} / \mathrm{s}$. This amount is similar to the seepage values measured later because there is only one very small surface-water inflow and no diversions in this reach. The apparent average gain for this reach was $0.9 \mathrm{ft}^{3} / \mathrm{s}$, or $0.5 \mathrm{ft}^{3} / \mathrm{s} / \mathrm{mi}$ gain (table 8 ).

The reach of McLeod Creek from the USGS streamflowgaging station McLeod Creek near Park City, Utah, to the confluence with Kimball Creek showed a net gain during each set of measurements. The measurements on June 24, 2004, show a gain of $1.4 \mathrm{ft}^{3} / \mathrm{s}$; however, this calculation does not account for any diversions or surface-water inflows. Total seepage gains for the other three measurement dates ranged from 1.9 to $2.6 \mathrm{ft}^{3} / \mathrm{s}$ (table 8 ). These gains decreased through the summer months as conditions became drier. Expressed as a percentage of the discharge measured at site MCC-1, the seepage ranged from a 34 to 54 percent gain, with an average gain of 42 percent (table 8 ). The apparent average total seepage gain for McLeod Creek was $2.1 \mathrm{ft}^{3} / \mathrm{s}$ (table 8). 


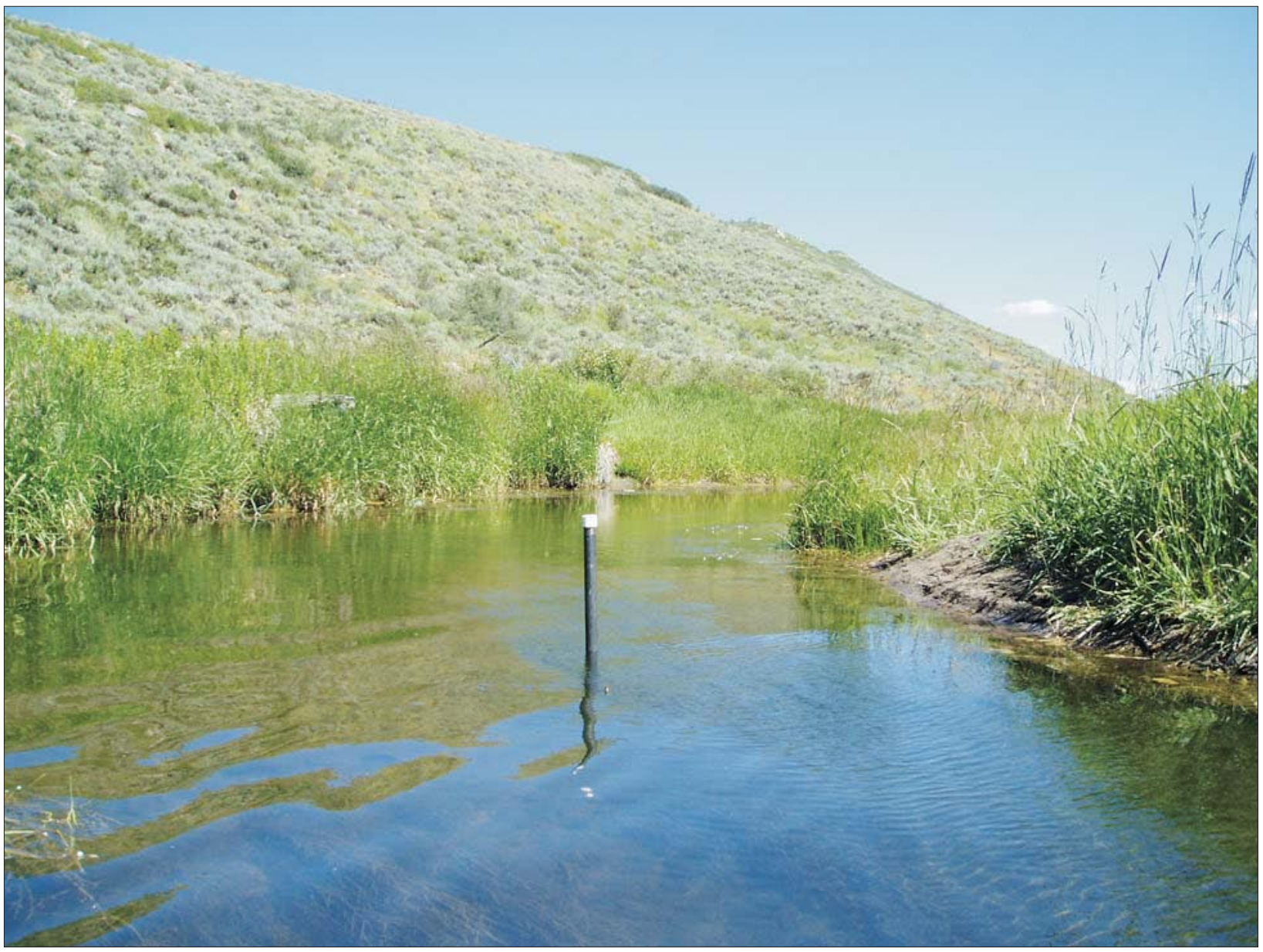

Figure 8. Streambed piezometer installed at site ECC-7, near Park City, Utah.

Table 8. Calculated seepage gains and losses for McLeod Creek near Park City, Utah

\begin{tabular}{|c|c|c|c|c|c|c|c|}
\hline Reach & $\begin{array}{l}\text { Length } \\
\text { (miles) }\end{array}$ & $\begin{array}{l}\text { June } 24,2004 \\
\text { gain (+) } \\
\text { or loss (-) } \\
\text { (cubic feet per } \\
\text { second) }\end{array}$ & $\begin{array}{c}\text { July } 30,2004 \\
\text { gain (+) } \\
\text { or loss (-) } \\
\text { (cubic feet per } \\
\text { second) }\end{array}$ & $\begin{array}{l}\text { August 30, } 2004 \\
\text { gain (+) } \\
\text { or loss (-) } \\
\text { (cubic feet per } \\
\text { second) }\end{array}$ & $\begin{array}{l}\text { October 1, } 2004 \\
\text { gain (+) } \\
\text { or loss (-) } \\
\text { (cubic feet per } \\
\text { second) }\end{array}$ & $\begin{array}{c}\text { Apparent } \\
\text { average gain (+) } \\
\text { or loss }(-) \\
\text { of reach } \\
\text { (cubic feet per } \\
\text { second) }\end{array}$ & $\begin{array}{c}\text { Apparent } \\
\text { average gain (+) } \\
\text { or loss (-) } \\
\text { of reach } \\
\text { (cubic feet per } \\
\text { second per mile) }\end{array}$ \\
\hline MCC-1 to MCC-2 & 2.17 & -5.1 & $1,20.2$ & $1,2-0.1$ & ${ }^{2} 0.3$ & ${ }^{3} 0.1$ & ${ }^{3} 0.0$ \\
\hline Total seepage & & ${ }^{4} 1.4$ & 2.6 & 1.9 & 1.9 & ${ }^{3} 2.1$ & \\
\hline Percent of MCC-1 & & ${ }^{4} 18$ & 54 & 39 & 34 & ${ }^{3} 42$ & \\
\hline
\end{tabular}

\section{${ }^{1}$ Return flow from MCC-R3 was not measured.}

${ }^{2}$ Seepage is in the range of measurement error.

${ }^{3}$ Apparent average calculated from measurements made on July 30, August 30, and October 1, 2004.

${ }^{4}$ No inflows or outflows were measured on this date; these values only reflect changes in discharge along the creek and are not considered to be seepage values. 


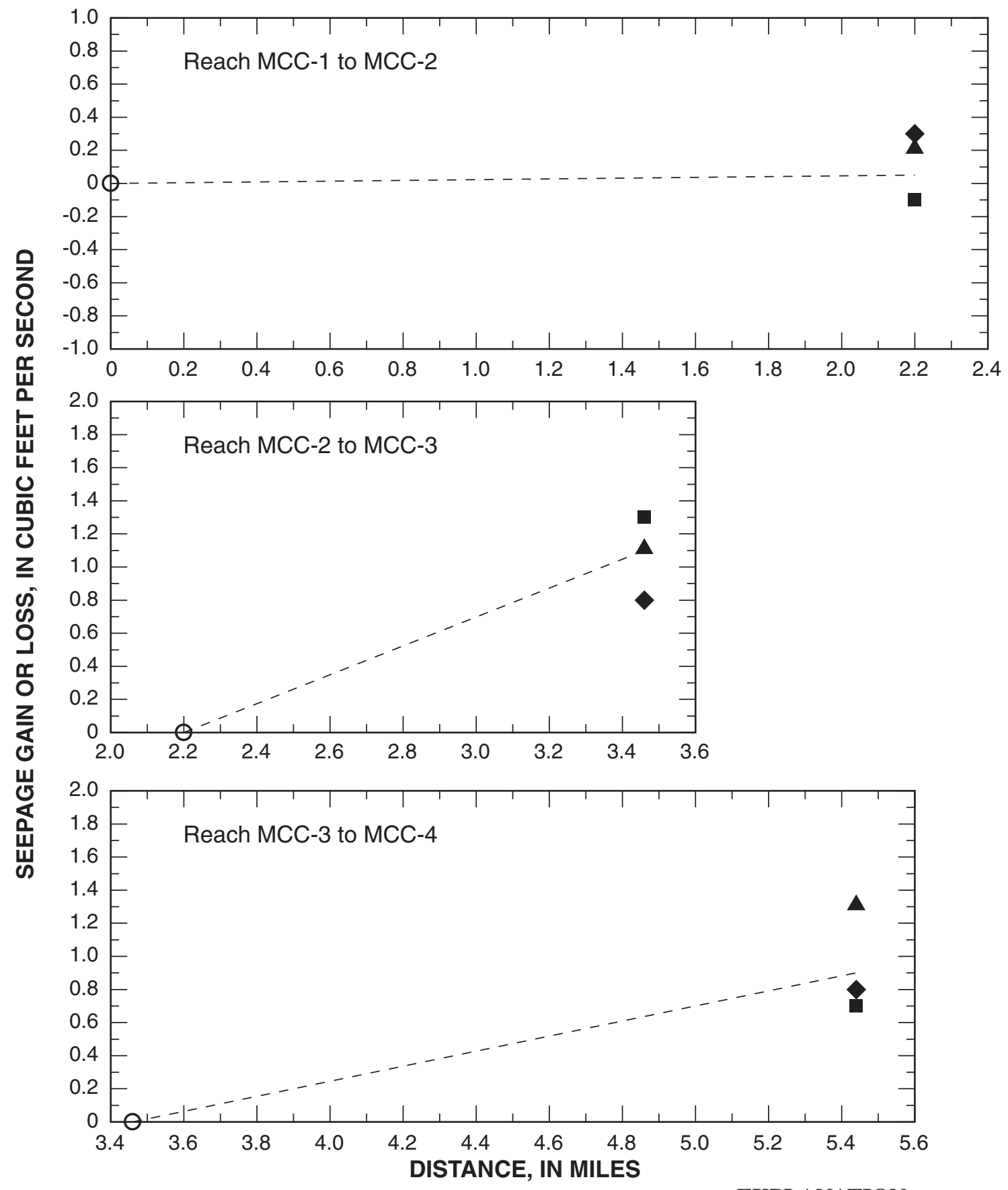

EXPLANATION

O Point from which change was computed

$\Delta$ Seepage measurement of July 30, 2004

- Seepage measurement of August 30, 2004

- Seepage measurement of October 1, 2004

- - - Apparent Average Seepage

Figure 9. Measured and apparent average seepage gain for reaches of McLeod Creek near Park City, Utah. 
A graph of discharge measured at the stations along McLeod Creek is shown in figure 10. A consistent pattern of flow throughout the summer can be seen. From site MCC1 to MCC-2 the creek consistently loses water. This reach contains the main water diversions. During the June 24, 2004, and October 1, 2004, measurements it appears that most of the water that is diverted from the upper section of McLeod Creek is returned downstream. This is because no irrigation was taking place at this time. During the July and August measurements, McLeod Creek gained water from site MCC-2 to MCC-3. However, the gains in this reach were less than the losses measured in the reach from site MCC-1 to MCC2. From site MCC-3 to MCC-4 there was a consistent gain throughout the summer, with the largest gains occurring in June when conditions were wetter.

\section{Seepage gains and losses for East Canyon Creek}

Eight main channel measurement sites and nine tributary sites were selected to evaluate seepage gains and losses along
East Canyon Creek (fig. 3). The computed seepage and the apparent average seepage, calculated from measurements made on June 24, July 30, August 30, and October 1, 2004, along East Canyon Creek are reported in table 9. The total gain or loss also is shown as a percentage of the flow measured at site ECC-1.

No consistent seepage gain or loss was observed in the reach of East Canyon Creek from site ECC-1 to ECC-2 (fig. 11). Seepage in this reach ranged from -0.8 to $1.4 \mathrm{ft}^{3} / \mathrm{s}$. The apparent average seepage was $0.0 \mathrm{ft}^{3} / \mathrm{s}$ (table 9). The $1.4 \mathrm{ft}^{3} / \mathrm{s}$ gain was measured on June 24, 2004. This gain may have been caused by soils and the wetland areas surrounding East Canyon Creek draining after wetter conditions in the spring. The measurement made on August 30, 2004, was in the range of the discharge measurement error. The July and October measurements showed a measurable seepage loss for this reach of -0.7 and $-0.8 \mathrm{ft}^{3} / \mathrm{s}$, respectively.

Seepage in the reach from site ECC-2 to ECC-3 consistently showed a minor loss (fig. 11) and ranged from -1.1 to $0.0 \mathrm{ft}^{3} / \mathrm{s}$ (table 9). The $-1.1 \mathrm{ft}^{3} / \mathrm{s}$ loss was measured on June 24 , 2004. The main diversion (OUT-2) to the Glenwild Golf Club pump is located in this reach of the creek. The seepage mea-

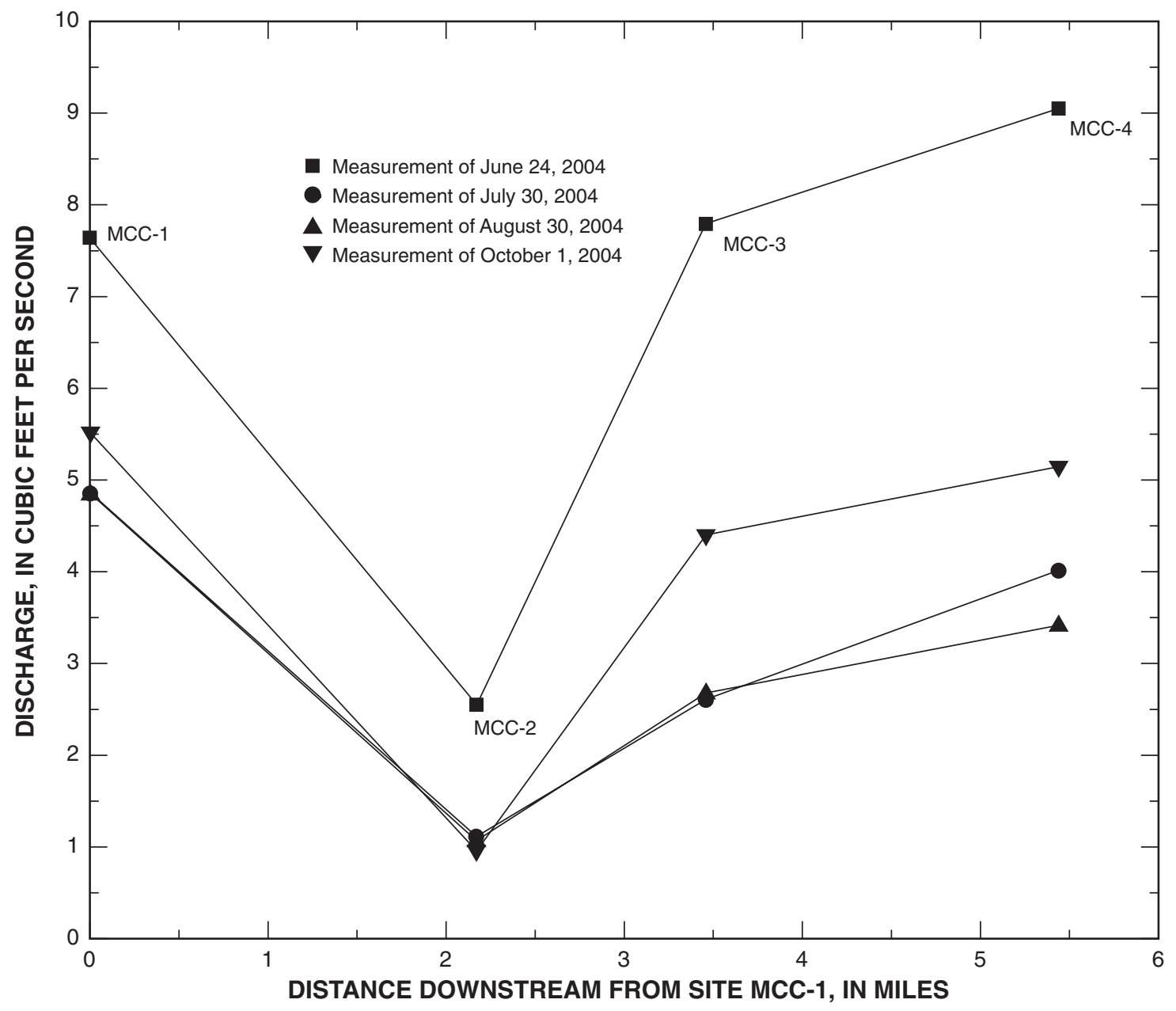

Figure 10. Discharge along McLeod Creek near Park City, Utah. 
sured on July 30 and October 1, 2004, was in the range of the discharge measurement error. The apparent average seepage loss for this reach was $-0.4 \mathrm{ft}^{3} / \mathrm{s}$ or $-0.4 \mathrm{ft}^{3} / \mathrm{s} / \mathrm{mi}$.

Seepage in the reach from site ECC-3 to ECC-4 ranged from -0.5 to $0.4 \mathrm{ft}^{3} / \mathrm{s}$ (table 9 ). The seepage measured on June 24, 2004, was in the range of the discharge measurement error. No consistent seepage gain or loss was observed in this reach (fig. 11). The apparent average seepage was $0.0 \mathrm{ft}^{3} / \mathrm{s}$.

Seepage from site ECC-4 to ECC-5 ranged from -1.4 to $0.4 \mathrm{ft}^{3} / \mathrm{s}$ (table 9). On June 24, 2004, the seepage measured was $-1.4 \mathrm{ft}^{3} / \mathrm{s}$. The seepage measured on August 30, 2004, was in the range of the natural fluctuation of discharge in East Canyon Creek. Seepage in this reach trended from a loss in June to a small gain at the beginning of October. The apparent average seepage for this reach is $-0.3 \mathrm{ft}^{3} / \mathrm{s}$, or $-0.4 \mathrm{ft}^{3} / \mathrm{s} / \mathrm{mi}$. However, this average is strongly biased by the measurement made in June.

Seepage from site ECC-5 to ECC-6 ranged from -1.0 to $0.6 \mathrm{ft}^{3} / \mathrm{s}$. The largest seepage loss of $-1.0 \mathrm{ft}^{3} / \mathrm{s}$ was measured on June 24, 2004 (table 9). No consistent seepage gain or loss was observed in this reach (fig. 11). The measurements in July and August showed seepage gains, while the October measurement showed a small loss. The apparent average seepage for this reach is $-0.1 \mathrm{ft}^{3} / \mathrm{s}$, or $-0.2 \mathrm{ft}^{3} / \mathrm{s} / \mathrm{mi}$.

Seepage from site ECC-6 to ECC-7 ranged from -0.2 to $0.4 \mathrm{ft}^{3} / \mathrm{s}$ (table 9). The measurements made on June 24 and August 30, 2004, were within the range of the discharge measurement error. The apparent average seepage for this reach is $0.1 \mathrm{ft}^{3} / \mathrm{s}$ or $0.1 \mathrm{ft}^{3} / \mathrm{s} / \mathrm{mi}$ (fig. 11).

Seepage from site ECC-7 to ECC-8 varied from -0.8 to $0.1 \mathrm{ft}^{3} / \mathrm{s}$ (table 9). The values measured on July 30 and October 1, 2004, were within the range of the discharge measurement error. The apparent average seepage for this reach is -0.4 $\mathrm{ft}^{3} / \mathrm{s}$ or $-0.4 \mathrm{ft}^{3} / \mathrm{s} / \mathrm{mi}$.
The total seepage lost or gained along the entire course of the East Canyon Creek study reach varied from $-2.0 \mathrm{ft}^{3} / \mathrm{s}$ measured on June 24, 2004, to $0.3 \mathrm{ft}^{3} / \mathrm{s}$ measured on August 30,2004 (table 9). This is a -19 percent loss to an 8 percent gain from site ECC-1 to ECC-8. The seepage gain measured on August 30, 2004, was in the range of natural discharge fluctuation measured at the upstream gaging station. The apparent average total seepage was $-1.0 \mathrm{ft}^{3} / \mathrm{s}$. The average seepage as a percentage of flow at site ECC- 1 was -14 percent. The largest percentage loss of -27 percent occurred during the July 30 , 2004, measurement.

A plot of the discharge measurements made along East Canyon Creek is shown in figure 7. This plot shows a fairly consistent pattern of discharge along the creek throughout the summer. The reaches with the greatest change in discharge are those that have the largest anthropogenic effects. Reach ECC-2 to ECC-3 shows a consistent loss in discharge. This is the result of an active diversion to the Glenwild Golf Club pump. Reach ECC-7 to ECC-8 shows a consistent gain caused by inflow from the East Canyon Water Reclamation Facility.

\section{Heat Tracing in East Canyon Creek}

Water temperature measured in East Canyon Creek and in the streambed piezometers at sites ECC-2, ECC-4, and ECC-7 is shown in figures 12-14, respectively. The surface-water temperature in East Canyon Creek has a diurnal variation that is controlled by the ambient air temperature. If this diurnal trend is seen in the subsurface, it is an indication that water is moving from the surface into the streambed.

At site ECC-2 during the end of July and August there appears to be a very small water-temperature fluctuation in the piezometer that corresponds with diurnal surface-water temperature. This indicates that a small amount of seepage to the streambed is occurring in this area. Seepage measured from

Table 9. Calculated seepage gains and losses for East Canyon Creek near Park City, Utah

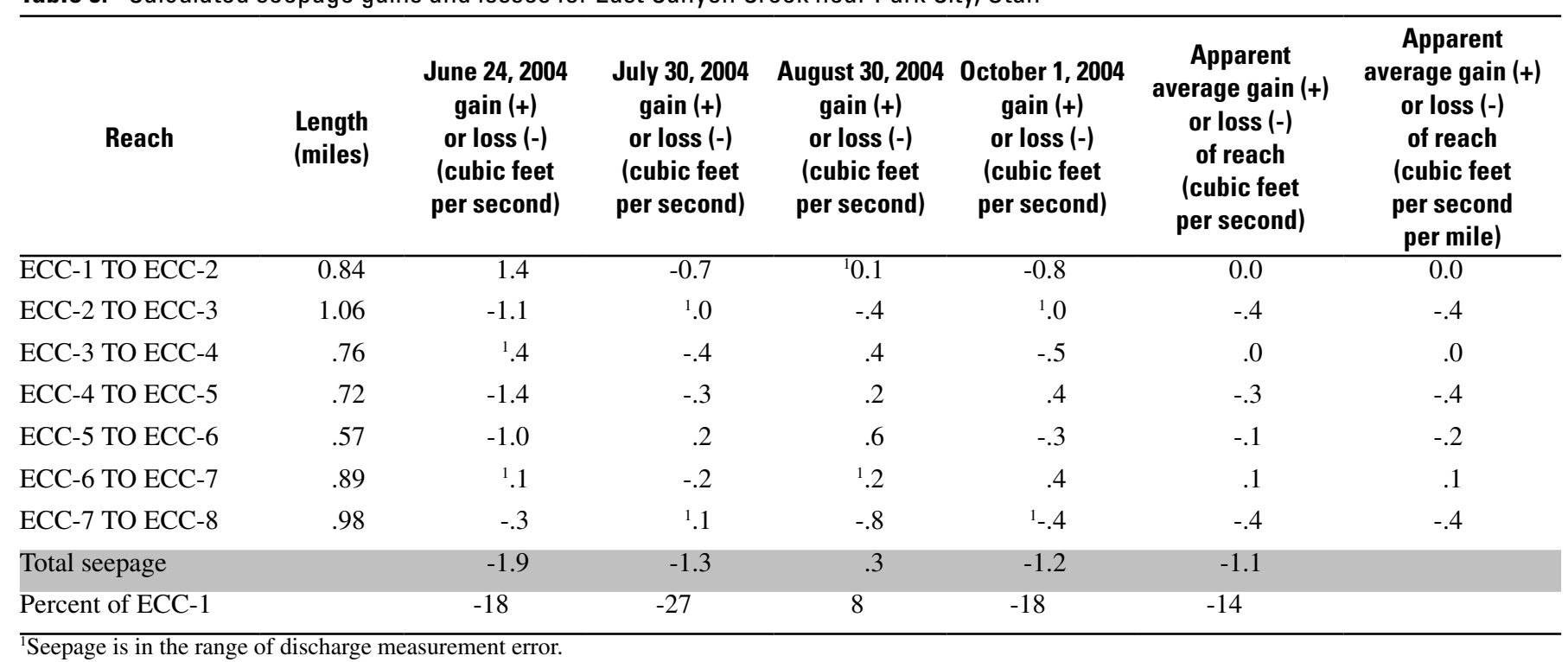

${ }^{\mathrm{T}}$ Seepage is in the range of discharge measurement error. 



\section{EXPLANATION}

$\bigcirc$ Point from which change was computed

- Seepage measurement of June 24, 2004

$\Delta \quad$ Seepage measurement of July 30, 2004

- Seepage measurement of August 30, 2004

- Seepage measurement of October 1, 2004 Apparent average seepage

Figure 11. Measured and apparent average seepage gain or loss for reaches of East Canyon Creek near Park City, Utah. 
sites ECC-1 to ECC-3 was $-0.7,-0.3$, and $-0.8 \mathrm{ft}^{3} / \mathrm{s}$ on July 30 , August 30, and October 1, 2004, respectively (table 9). The diurnal variation in the piezometer data was less pronounced in September and October. Although it is not indicated by the seepage measurements made in October, this attenuation may be caused by a decrease in seepage loss in the immediate area around site ECC-2.

A good relation between the surface and streambed water-temperature profiles appears to exist at site ECC-4. The peak daily water temperature occurs approximately 8 hours later in the piezometer than in the surface water. This is likely a result of the travel time of the water moving to the depth of the temperature sensor. Measured seepage from site ECC-3 to ECC-5 was $-0.7,0.6$, and $-0.1 \mathrm{ft}^{3} / \mathrm{s}$ on July 30 , August 30 , and October 1, 2004, respectively. A diurnal fluctuation in the piezometer temperature data was observed throughout the summer at this location. The seepage gain measured on August 30, 2004, was not observed in the temperature data recorded at site ECC-4. This may have been caused by seepage gains that were occurring elsewhere between ECC-3 and ECC-5 on this date.

A diurnal water-temperature fluctuation was seen in the piezometer installed at site ECC-7. This fluctuation appears to attenuate in September and October. This is consistent with a decrease in measured seepage that was observed between site ECC-6 and ECC-8. Measured seepage from site ECC-6 to ECC -8 was $-0.1,-0.6$, and $0.0 \mathrm{ft}^{3} / \mathrm{s}$ on July 30 , August 30 , and October 1, 2004, respectively (table 9).

Water-temperature data from the three piezometers indicate seepage losses in the areas of sites ECC-2, ECC-4, and ECC-7. Seepage losses appear to be the least at site ECC-2 where the temperature fluctuation was slight. At sites ECC-2 and ECC-7 the temperature fluctuation appears to attenuate in September and October, indicating a decrease in the amount of water moving to the streambed at the end of summer.

\section{Summary}

Seepage investigations on McLeod Creek between the USGS streamflow-gaging station at McLeod Creek near Park City, Utah, and its confluence with Kimball Creek during the summer of 2004 indicate that this part of the creek overall is a gaining reach. Total seepage gains ranged from 1.9 to 2.6 $\mathrm{ft}^{3} / \mathrm{s}$. This is a 34 to 54 percent gain. The apparent average total seepage for McLeod Creek was $2.2 \mathrm{ft}^{3} / \mathrm{s}$, or an average 42 percent gain. The reach from MCC-1 to MCC-2, which is the upper $2 \mathrm{mi}$ of the creek from the gaging station to the West Grade Canal irrigation return, showed no consistent gain or loss. The lower reaches of the creek from MCC-2 to MCC-4 had consistent seepage gains on the order of 0.5 to $0.8 \mathrm{ft}^{3} / \mathrm{s} / \mathrm{mi}$.

Seepage investigations from USGS streamflow-gaging station East Canyon Creek below I-80 Rest Stop near Park City, Utah, to station East Canyon Creek near Jeremy Ranch, Utah, indicate that this part of East Canyon Creek is a slightly losing reach. Total seepage losses ranged from -1.9 to 0.3 $\mathrm{ft}^{3} / \mathrm{s}$. This is a range of 8 to -27 percent from discharge measured at the upstream gaging station. The measurement on August 30 showed an overall gain; however, this gain was small and in the range of natural discharge fluctuations and measurement error. Reaches of the creek that had the most consistent seepage losses were from ECC-2 to ECC-3 and from ECC-7 to ECC-8. Seepage losses in these sections were $-0.4 \mathrm{ft}^{3} / \mathrm{s} / \mathrm{mi}$. Other reaches showed inconsistent small seepage gains and losses. The apparent average total seepage loss for the study reach on East Canyon Creek was $-1.1 \mathrm{ft}^{3} / \mathrm{s}$, or -14 percent.

Water-temperature data from three shallow streambed piezometers installed in East Canyon Creek indicates the movement of surface water into the streambed at sites ECC2, ECC-4, and ECC-7. This indicates that a seepage loss is occurring at these sites. No indications of a seepage gain were observed in the streambed piezometers. The movement of water to the streambed appears to decrease in September and October.

Although the amount of seepage loss in the individual reaches of East Canyon Creek are near the range of measurement and calculation limitations, when summed together, the measurements indicate that the study reach is losing water. This is supported by water-temperature data recorded at the three piezometer locations. 

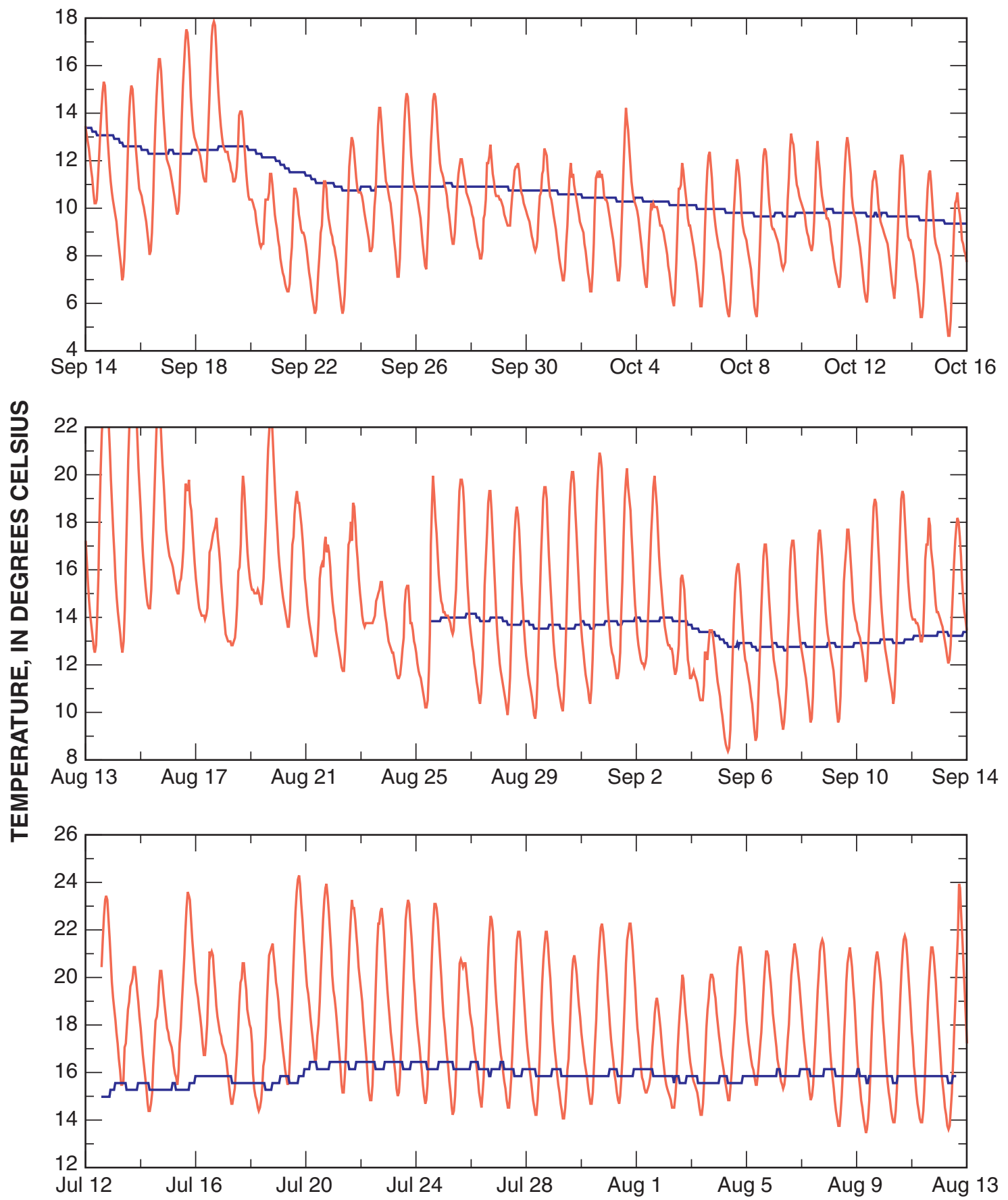

- Surface-water temperature

Subsurface-water temperature

Figure 12. Water temperature and streambed piezometer temperature in East Canyon Creek at site ECC-2, near Park City, Utah. 

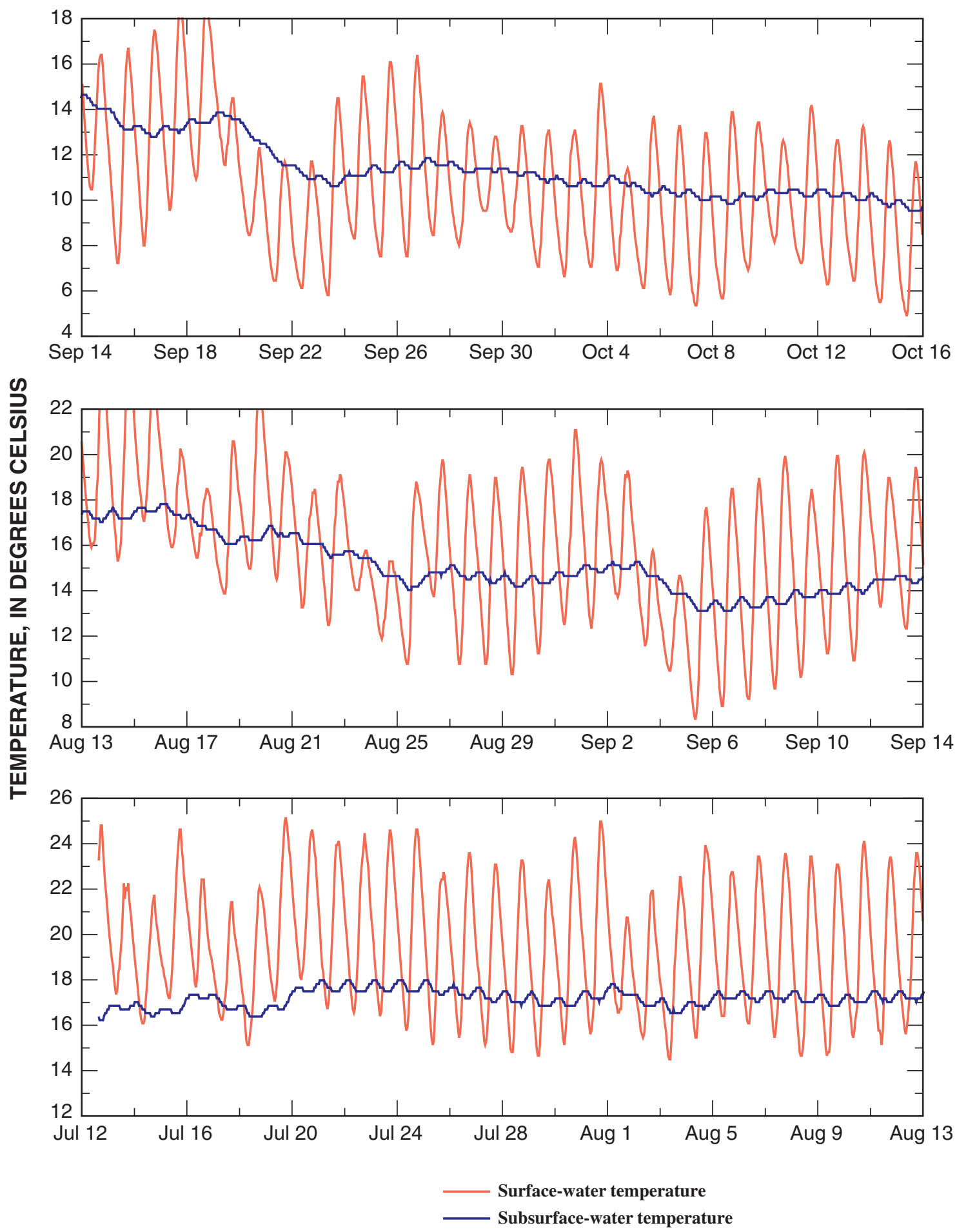

Figure 13. Water temperature and streambed piezometer temperature in East Canyon Creek at site ECC-4, near Park City, Utah. 


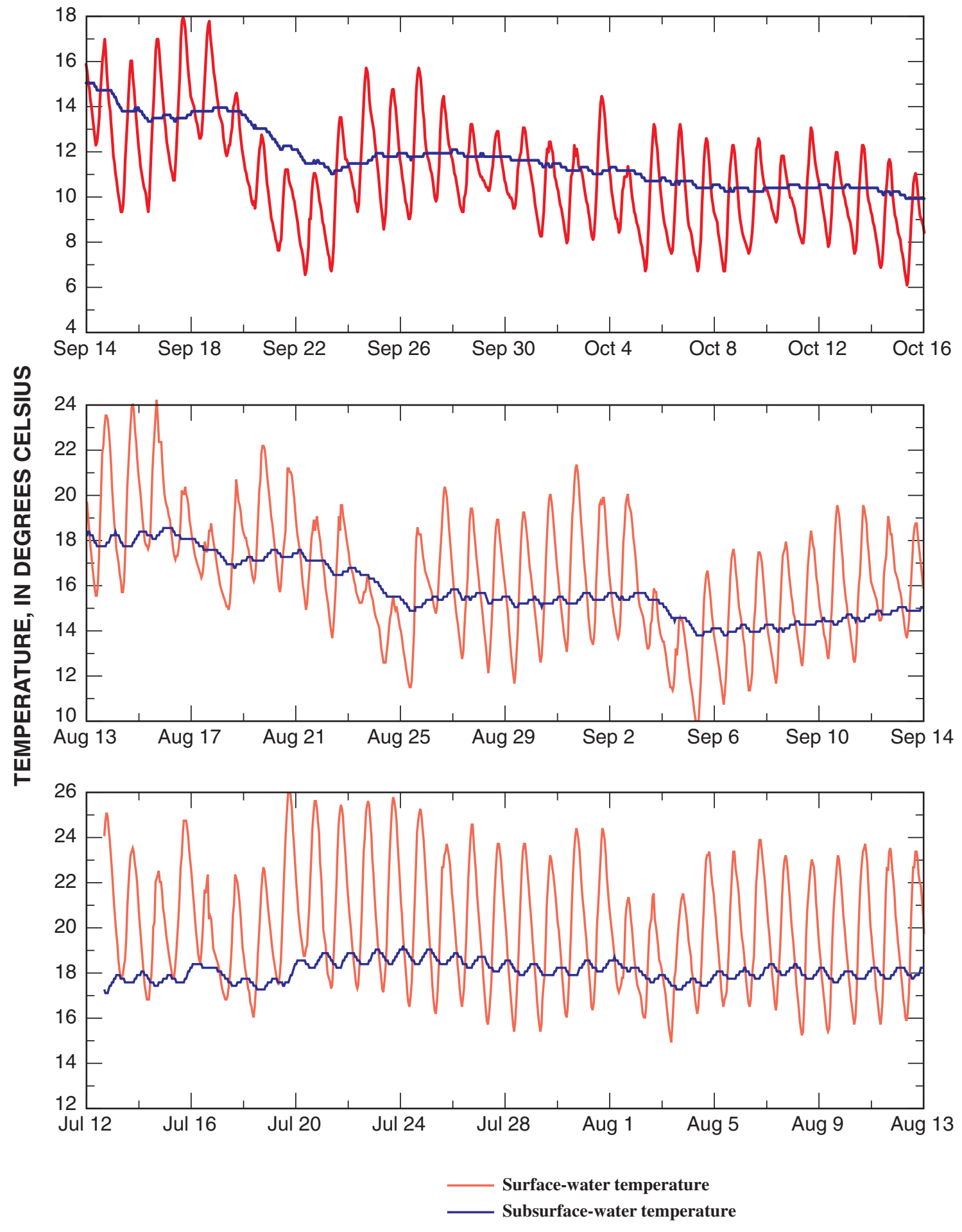

Figure 14. Water temperature and streambed piezometer temperature in East Canyon Creek at site ECC-7, near Park City, Utah. 


\section{References Cited}

Brooks, L.E., Mason, J.L., and Susong, D.D., 1998, Hydrology and Snowmelt simulation of Snyderville Basin, Park City, and adjacent areas, Summit County, Utah: Utah Department of Natural Resources Technical Publication No. $115,84 \mathrm{p}$.

Buchanan, T.J., and Somers, W.P., 1969, Discharge measurements at gaging stations: U.S. Geological Survey Techniques of Water-Resources Investigations, book 3, chap. A8, $66 \mathrm{p}$.

Downhour, P.A., and Brooks, L.E., 1996, Selected hydrologic data for Snyderville Basin, Park City, and adjacent areas, Summit County, Utah, 1967-95: U.S. Geological Survey Open-File Report 96-494, 52 p.

Holmes, W.F., Thompson, K.R., and Enright, M., 1986, Water resources of the Park City area, Utah, with emphasis on ground water: Utah Department of Natural Resources Technical Publication No. 85, 81 p.

Stonestrom, D.A., and Constantz, J., eds., 2003, Heat as a tool for studying the movement of ground water near streams, U.S. Geological Survey Circular 1260, 96 p.

Wilde, F.D., Radtke, D.B., eds., chapter sections variously dated, Field measurements: U.S. Geological Survey Techniques of Water-Resources Investigations, book 9, chap. A6, accessed June 1, 2004, at url http://pubs.water.usgs. gov/twri9A6 


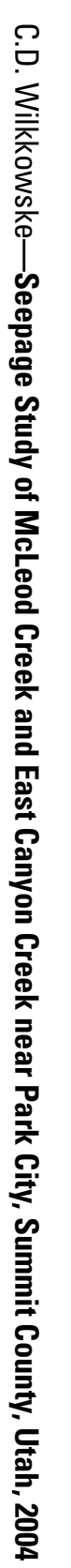

9 Printed on recycled paper 